\title{
Therapeutic Potential of Targeting the Th17/Treg Axis in Autoimmune Disorders
}

\author{
Patrizia Fasching, Martin Stradner, Winfried Graninger, Christian Dejaco * and Johannes Fessler \\ Department of Rheumatology and Immunology, Medical University of Graz, Auenbruggerplatz 15, 8036 Graz, \\ Austria; patriziafasching@gmx.at (P.F.); martin.stradner@medunigraz.at (M.S.); \\ winfried.graninger@medunigraz.at (W.G.); johannes_fessler@hotmail.com (J.F.) \\ * Correspondence: christian.dejaco@gmx.net
}

Academic Editor: Chun Kwok Wong

Received: 12 December 2016; Accepted: 10 January 2017; Published: 14 January 2017

\begin{abstract}
A disruption of the crucial balance between regulatory T-cells (Tregs) and Th17-cells was recently implicated in various autoimmune disorders. Tregs are responsible for the maintenance of self-tolerance, thus inhibiting autoimmunity, whereas pro-inflammatory Th17-cells contribute to the induction and propagation of inflammation. Distortion of the Th17/Treg balance favoring the pro-inflammatory Th17 side is hence suspected to contribute to exacerbation of autoimmune disorders. This review aims to summarize recent data and advances in targeted therapeutic modification of the Th17/Treg-balance, as well as information on the efficacy of candidate therapeutics with respect to the treatment of autoimmune diseases.
\end{abstract}

Keywords: Th17-cells; regulatory T-cells; autoimmunity; ROR $\gamma \mathrm{t}$; Foxp3

\section{Introduction}

Autoimmunity comprises a number of pathological conditions and disorders with distinct appearances and characteristics, all sharing the common hallmark of impaired self-tolerance. In healthy individuals, the mechanisms of central and peripheral tolerance ensure a proper regulation of the immune system thus preventing autoimmunity. Regulatory T-cells (Tregs) are crucial for the maintenance of peripheral immunological tolerance. Impairments in Treg numbers or function have been investigated in various autoimmune diseases (AIDs) [1]. More recently, autoimmunity has been linked to an impaired balance between Tregs and Th17-cells, an effector T-cell subset described to promote inflammation by acting as Treg antagonists. A shift in the Th17/Treg equilibrium towards the pro-inflammatory Th17 side has been reported in several autoimmune disorders including rheumatoid arthritis (RA), ankylosing spondylitis (AS), psoriasis and psoriatic arthritis (PsA), multiple sclerosis (MS), systemic lupus erythematosus (SLE), inflammatory bowel disease (IBD), as well as Crohn's disease (CD) [2-4]. Moreover, several drugs with the potential to modify Treg- and in particular Th17-responses, have already shown to be effective and received approval for the treatment of some of these disorders [5-11]. These findings have corroborated existing evidence on the involvement and reciprocal role of Tregs and Th17-cells in autoimmune inflammation, thus highlighting the importance of investigating new therapeutic strategies in this regard. This review aims to summarize recent data and advances in targeted therapeutic modification of the Th17/Treg-balance, as well as on the efficacy of candidate therapeutics with respect to the treatment of AIDs.

\section{Treg-Cells}

Although a wealth of regulatory immune cells $[12,13]$ have been identified, CD4+ Tregs remain the most extensively studied cell-type with immunosuppressive properties. Tregs can use a variety of mechanisms to induce immunosuppression, including indirect suppression via the expression of 
inhibitory cytokines, metabolic disruption of target T-cells, cytolysis, and regulation of dendritic cell maturation and function [14]. Tregs are divided into two different subsets, depending on their origin. While natural Tregs (nTregs) are derived from the thymus, inducible Tregs (iTregs) develop from naïve T-cell precursors in the periphery. Thymic development of nTregs depends on TCR-stimulation in combination with CD28 co-stimulation. CD28 is furthermore essential for homeostatic proliferation and survival of nTregs in the periphery [15]. In contrast, development of iTregs requires the presence of IL-2 and transforming growth factor (TGF)- $\beta$ instead of CD28 co-stimulation [16].

\subsection{Transcription Factors and Surface Markers}

Treg-cell lineage commitment is pivotally promoted by the expression of transcription factor forkhead box P3 (Foxp3). Divers mutations in the human FOXP3 gene result in an allotropic syndrome of multi-organ autoimmunity (immune dysregulation, polyendocrinopathy, enteropathy, X-linked (IPEX) syndrome [17]) and similar effects were observed in the scurfy mouse, a murine model carrying a mutation in Foxp3 [18]. Moreover, continued expression of Foxp3 is required to maintain function and lineage identity of mature peripheral Tregs [19]. Transcription of FOXP3 is activated by signal transducer and activator of transcription (STAT) 5, another transcription factor shown to influence Treg differentiation and survival [20].

Foxp3 is one of the most specific markers to identify Tregs; however, Foxp3+ cells without suppressive function are also present in humans. Another notable limitation of this marker is the fact, that cells must be permeabilized in order to stain Foxp3 intracellularly. Permeabilized cells are not viable anymore and can thus not be used for further functional testing. Other, reliable markers expressed on the surface of Tregs are needed to identify this cell population for functional experiments.

Initially, Treg characterization was mainly based on their elevated expression of surface IL-2 receptor $\alpha$-chain (CD25) until it was evident that CD25 can also be elevated in activated T-cells lacking suppressive function. Various additional surface-markers were proposed to define Tregs including cytotoxic T-lymphocyte associated Ag-4 (CTLA-4) [21], adhesion molecule CD62L [22], glucocorticoid-induced tumor necrosis factor receptor (GITR) [23], programmed cell death-1 (PD-1) [24] and many others, while CD49d, CD127, CD26 and CD6 were proposed as negative markers [25-29]. However, as none of these molecules is Treg-specific, the use of a combination of several markers is now recommended for a reliable identification of Tregs.

\subsection{Cytokines}

One of the features attributed to Tregs is the secretion of cytokines exerting suppressive function on various immune cell subsets. The major Treg-cytokines include TGF- $\beta$ and interleukin (IL)-10 [14]. TGF- $\beta$ is pivotal for the maintenance of immunological tolerance through interference with differentiation, proliferation and survival of lymphocytes and other immune cells [30]. Targeted deletion of the TGF- $\beta$ RII receptor in T-cells resulted in early-onset lethal autoimmunity in mice [30,31]. Moreover, T-cell specific TGF- $\beta$ RII deficiency resulted in the emergence of a highly pathogenic T-cell population overexpressing granzymes, perforin, death receptor ligand FasL and interferon (IFN)- $\gamma$, which has been assumed to cause this autoimmune disease [31]. Tregs, however, are not the sole source of TGF- $\beta$ secretion, and there is a multiplicity of effects exerted by TGF- $\beta$ on its target cells, as reviewed in detail elsewhere [32,33]. IL-10, in contrast, seems to be predominantly essential for the control of inflammation at environmental interfaces such as lungs and colon. IL-10 does not only induce suppression of pathogenic Th17-cell responses [34-36], it is also required to maintain Treg suppressive activity and expression of Foxp3. Besides, IL-10 was reported to interfere with Th1-cell migration to intestinal inflammatory sites [37,38]. Apart from that, nTregs were reported to be a natural source of IL-35, thereby triggering differentiation of naïve T-cells into a distinct iTreg-subset exerting its suppressive function exclusively via production of IL-35 (iTr35-cells) [39]. Notably, iTr35-cells differ from Foxp3+ Treg-subsets as they lack Foxp3 expression [39]. Presumably, IL-35 is required for maximal suppressive function of Foxp3+ Tregs and has been suggested to contribute to the maintenance of 
immune tolerance in the gut [39-41]. The exact physiological role of IL-35 in vivo, however, is under debate and requires further investigation.

\section{Th17-Cells}

Since their identification, Th17-cells have been extensively studied and were soon accepted as a distinct CD4+ helper T-cell lineage [42,43]. A bulk of evidence from numerous studies has demonstrated their malicious, pro-inflammatory involvement in various autoimmune disorders [2]. However, this cell subset also has a physiologic role in the immune system by conferring protective function against microbial pathogens (including fungi, bacteria, and viruses) at mucosal surfaces $[44,45]$.

\subsection{Transcription Factors and Surface Markers}

The differentiation of Th17-cells is directed by their master transcription factor retinoic acid-related orphan receptor $\gamma \mathrm{t}(\mathrm{ROR} \gamma \mathrm{t})$, a specific transcript of the RORC gene. Interestingly, TGF- $\beta$ is initially required for the development of both, iTregs and Th17-cells, by triggering the expression of their differentiating transcription factors, Foxp3 and ROR $\gamma \mathrm{t}$, respectively [46]. In fact, both transcription factors are initially up-regulated after naïve CD4+ T-cells encounter TGF- $\beta$ [47]. Whether subsequent differentiation of the cells is skewed towards a regulatory phenotype or a pro-inflammatory Th17 phenotype depends mainly on the surrounding cytokine milieu. Up-regulated Foxp3 initially binds to ROR $\gamma t$ thereby inhibiting the development of Th17-cells and favoring Treg development [48]. However, the presence of pro-inflammatory cytokines such as IL- 6 and IL-21 can abrogate this TGF- $\beta$-dependent, Foxp3-mediated inhibition of ROR $\gamma t$ via activation of transcription factor STAT3 [46,49] (Figure 1). Eventually, this leads to the differentiation of Th17-cells and up-regulation of the receptor IL-23R. IL-23 then provides a positive feedback loop for the maintenance, expansion and proper function of Th17-cells [50]. Increased surface expression of IL-23R is characteristic for Th17-cells and might be used to identify this cell population [51]. Further surface markers suggested to serve as Th17-identifiers are chemokine receptors CCR6 and CCR4, both associated with skin homing of cells [52]. Moreover, CXCR3 negativity helps to distinguish CCR6+ Th17-cells from CXCR3+ CCR6+ Th1/17-cells. The latter is a distinct T-cell population exhibiting both Th1 and Th17 characteristics. More recently, the C-type lectin CD161 was reported to be a useful surface marker for Th17-cell characterization given that IL-17 producing cells originate from CD161+ T-cells [53]. A combination of different markers, however, might be the best approach for reliable Th17-cell identification (similar to the strategy to identify Tregs as discussed above).

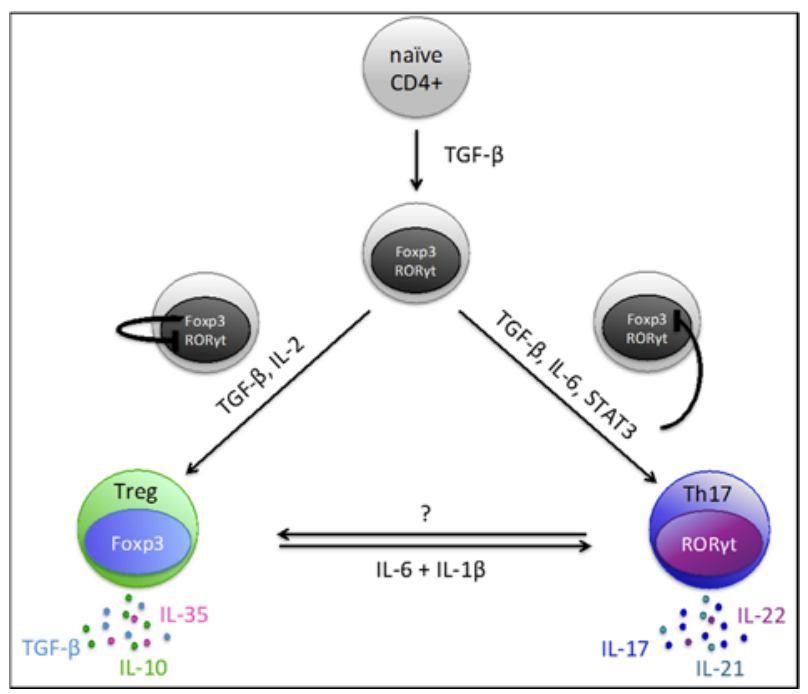

Figure 1. Development and trans-differentiation pathways of Tregs and Th17-cells. 


\subsection{Cytokines}

IL-17A (commonly referred to as IL-17) and IL-17F are the key effector cytokines of Th17-cells. During Th17-cell differentiation, ROR $\gamma \mathrm{t}$ directly binds to the promoter region of IL-17A, thereby orchestrating its transcription [48]. IL-17 is involved in inflammatory responses by stimulating cell types of both, immune and non-immune nature. The effect of IL-17 in this context is to indirectly promote neutrophil recruitment via induction of CXCL8 in macrophages, epithelial and endothelial cells and fibroblasts [54]. Additionally, tumor necrosis factor (TNF)- $\alpha$ and granulocyte-macrophage colony-stimulating factor (GM-CSF) secreted by Th17-cells also contribute to neutrophil recruitment, activation and survival [55]. Furthermore, IL-17 induces CCL20 expression in various cell types found at sites of chronic inflammation, thereby enhancing attraction of additional Th17-cells, which express CCR6, the receptor for CCL20. Other molecules such as IL-22, IL-26 and IL-21 are also part of the characteristic Th17-signature $[47,49,56]$. These cytokines feed another positive loop amplifying the Th17 response in an autocrine manner [50,57]. IL-22 seems to be crucially involved in the pathogenesis of psoriasis and RA [58,59] whereas IL-26 most likely contributes to the pathogenesis of intestinal inflammation [60].

\subsection{Pathogenic vs. Non-Pathogenic}

Although Th17-cells were first recognized due to their pathogenic involvement in autoimmune inflammation, accumulating evidence points toward a considerable heterogeneity of the Th17-lineage. For example, a non-pathogenic subset of Th17-cells has been identified, which has a physiologic role in the protection of intestinal barrier function $[44,45]$. This led to the conclusion that Th17-cells are not uniform in function. Further analyses revealed that Th17-cell differentiation in the presence of TGF- $\beta 1$ and IL-6 results in cells co-producing IL-17 and IL-10 [61]. These cells are assigned to the non-pathogenic subset of the Th17-lineage, as they are incapable of promoting autoimmune inflammation and might even act anti-inflammatory. On the other hand, differentiation of highly pathogenic Th17-cells from naïve precursor-cells was reported to occur independently of TGF- $\beta$ signaling in presence of IL-23, IL-6 and IL-1 $\beta$ [62,63]. Lee et al. [64] reported that IL-23 exposure resulted in a transcriptomic switch in differentiating Th17-cells thereby triggering Th17-pathogenicity via induction of a set of unique transcription factors and induction of TGF- $\beta 3$ production. They support their concept by demonstrating that TGF- $\beta 3$ and IL- 6 were sufficient to induce differentiation of pathogenic Th17-cells in in vitro experiments [64]. More recently, the serum/glucocorticoid regulated kinase 1 (SGK1) was reported to be critical for the generation of pathogenic Th17-cells by deactivating Foxo1, a direct repressor of IL-23R expression [65]. CD5L is another candidate molecule described to regulate Th17-pathogenicity. Loss of CD5L converts non-pathogenic Th17-cells into pathogenic ones that induce autoimmunity [66]. The mechanism by which CD5L regulated Th17-pathogenicity is based on alterations of the cellular fatty acid composition, eventually resulting in ROR $\gamma t$ ligand restriction [66]. Collectively, these studies indicate that there exist various subsets of Th17-cells with distinct function and pathogenic capacity.

\section{Th17/Treg Plasticity and Balance}

Shared requirement of TGF- $\beta$ and the reciprocal regulation of their master transcription factors ROR $\gamma \mathrm{t}$ and Foxp3 suggest a dichotomy in the generation of Th17-cells and Tregs. More importantly, there is a reported phenotypic and functional plasticity in both populations allowing differentiated cells to "re-"differentiate (Figure 1).

For example, IL-6 does not only enhance Th17-differentiation via STAT3 activation in naïve T-cells but was also shown to promote re-differentiation of Tregs into Th17-cells in presence of TGF- $\beta$ and IL-1 [67]. Similar observations were published by Deknuydt et al. [68] after combined in vitro treatment of isolated Tregs with IL-6 and IL-1 $\beta$, but not with IL-6 alone. This finding is in line with the previously reported resistance of TGF- $\beta$-induced Tregs to be skewed into the Th17-direction in a cell culture 
setting with IL-6 and IL-2 [69]. This result highlights the importance of IL-1 $\beta$ in this re-polarization process. A recent study by Komatsu et al. [70] reported CD25lo Foxp3+CD4+ T-cells obtained from Foxp $3^{\text {hCD2}}$ knock-in mice to preferentially loose Foxp3-expression and acquire expression of IL-17 upon adoptive transfer into arthritic mice. These exFoxp3 Th17-cells eventually accumulate in inflamed joints of these animals. Conversely, Gagliani et al. [71] more recently reported reprogramming of inflammatory Th17-cells into IL-10 producing cells with regulatory functions. Clustering analysis of Th17-relevant genes revealed that these exTh17-cells have undergone transcriptional reprogramming and subsequently clustered together with Tr1-cells, a regulatory T-cell subset characterized by secretion of IL-10 but lacking Foxp3 expression. Gagliani et al. referred to this subset as $\operatorname{Tr} 1^{\text {exTh17}}$. Moreover, a complete functional trans-differentiation from Th17 into regulatory Tr1-cells was suggested as these $\operatorname{Tr} 1{ }^{\text {exTh17 }}$ cells were furthermore shown to prevent Th17-cell mediated colitis in the respective mouse model. Overall, these studies illustrate the ability of Th17-cells and Tregs to undergo phenotype conversion. The physiological role of this phenotypic and functional adaptation of these cells to changing environmental conditions may lie in maintenance of an appropriate immune-regulation in response to the presence of certain microbes, cytokines and other signals from innate immune cells. As an imbalance between Th17-cells and Tregs is observed in autoimmunity, the plasticity of these cells could be exploited in order to develop more effective therapies that will recover immune tolerance while avoiding adverse effects that go along with therapies of systemic immunosuppression.

\section{Therapeutic Approaches: Molecules Influencing the Th17/Treg Axis}

In the past years, accumulating evidence highlighted a shift in the Th17/Treg equilibrium towards the pro-inflammatory Th17-program, which is assumed to contribute to the pathogenesis of chronic inflammatory disorders such as psoriasis, PsA, RA, AS, SLE, MS, IBD and CD [2-4].

Various drugs with the potential to modify Treg- and in particular Th17-responses have already proven efficacy and received approval for the treatment of certain AIDs while others are currently being tested in clinical trials (Figure 2). Nevertheless, identification and testing of additional candidate molecules is an incessant research aim. Generally, therapeutic approaches are multidirectional and comprise direct targeting of Th17-related cytokines, cytokine receptors, intracellular signaling pathways, as well as inhibiting Th17- and enhancing Treg-specific transcription factors.

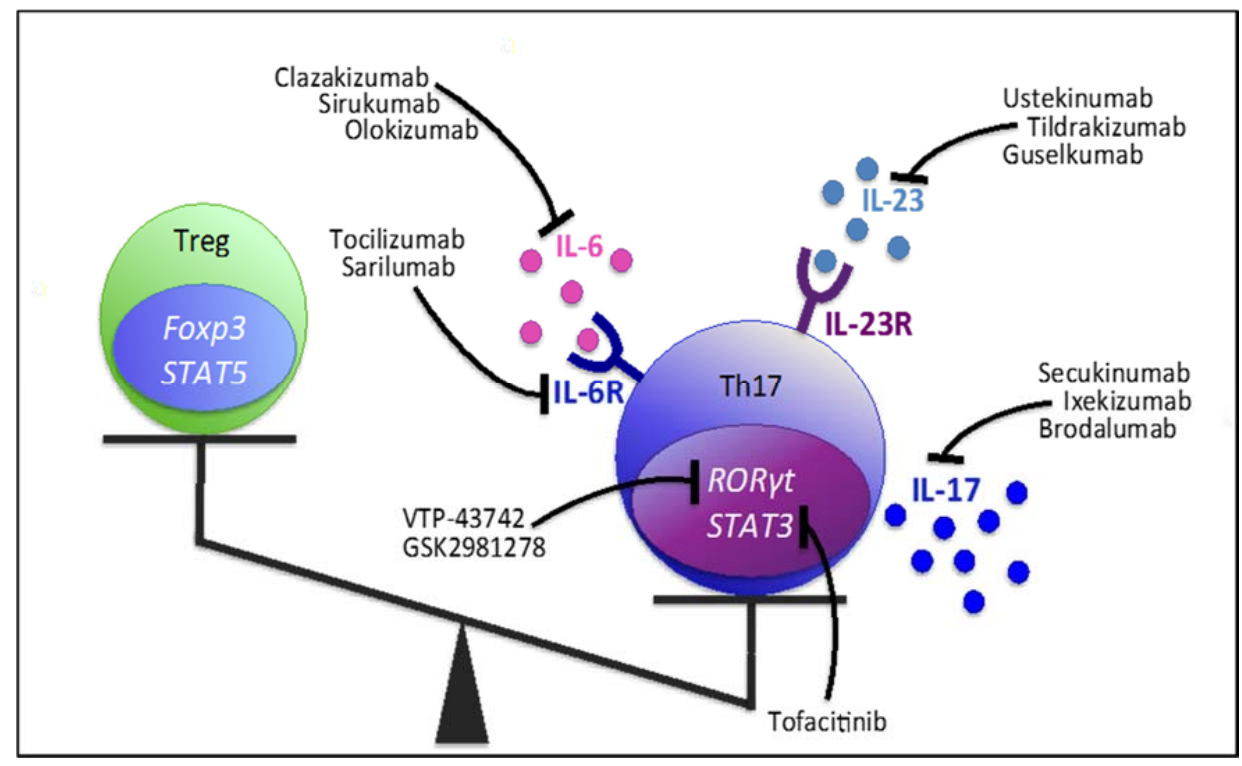

Figure 2. Therapeutic tools targeting Th17-cell cytokines, cytokine receptors and transcription factor pathways facilitate correction of the Th17/Treg imbalance in favor of the Treg-population. All Th17-modifying agents listed in this figure are either approved or are currently studied in clinical trials. 


\subsection{Targeting Th17-Related Cytokines and Receptors}

\subsubsection{IL-17}

IL-17 is the most prominent effector cytokine of Th17-cells and is implicated in a variety of inflammatory diseases [3]. This led to the conclusion that neutralization of IL-17, although not directly inducing a re-balance of Th17/Treg-cell ratio can abrogate IL-17-mediated pathogenic effects in autoimmune settings. Several IL-17 neutralizing monoclonal antibodies have been developed in recent years including secukinumab (AIN457), ixekizumab (LY2439821) and brodalumab (AMG827). Multiple clinical trials yielded impressive therapeutic effects of all three molecules [5-8,72] leading to the approval of secukinumab for psoriasis, PsA and AS, and ixekizumab for psoriasis [73-76]. Besides, ongoing clinical trials are evaluating the efficacy of ixekizumab in patients with active PsA (NCT01695239) and AS (NCT02696785, NCT02696798, NCT02757352).

In RA patients, IL-17 neutralization yielded inconsistent results, with some studies reporting significant clinical response and improvements in patient-reported outcomes [77-79], whereas others failed to meet the primary efficacy end points [80-82]. Importantly, approaches of IL-17 neutralization in $C D$ were terminated due to high rates of serious adverse events and fungal infections, overall resulting in a worsening of the disease while having no beneficial impact [83,84]. The explanation for the clear failure of IL-17 neutralization in CD is most likely because of the protective role of IL-17 at mucosal surfaces where it confers host defense and contributes to the maintenance of immune homeostasis [85].

\subsubsection{IL-23}

Years of research compellingly illustrated the requirement of IL-23 for expansion and maintenance of Th17-cells and recently also for their conversion of non-pathogenic cells with a protective role at mucosal barriers into highly pathogenic cells that promote inflammation [86,87]. IL-23 is a heterodimeric cytokine composed of two subunits, p19 and p40. The latter subunit is shared by the Th1-inducing cytokine IL-12 [88]. In psoriasis patients, p40 and p19 mRNA levels were higher in affected compared to normal skin whereas mRNA of the second IL-12 subunit (p35) was decreased in the lesions [89]. Pre-clinical psoriasis models further indicated that IL-23, but not IL-12, is able to drive excessive growth and abnormal differentiation of keratinocytes in murine skin [89]. Moreover, genetic abrogation of the p19 subunit of IL-23 in mice resulted in resistance to the development of experimental autoimmune encephalomyelitis (EAE), the most commonly used experimental model for human MS [90]. Similarly, resistance against joint inflammation was observed in p19-lacking mice with collagen induced arthritis (CIA), a mouse model of RA [91]. In this study, IL-23-deficiency was linked to the absence of IL-17-producing CD4+ T-cells [91]. Another mouse study reported that both, anti-IL-12/23p40 and anti-IL-23p19 antibodies markedly lowered transcript levels of Th17-cytokines such as IL-17 and IL-22 [92]. Blocking IL-23 and its cognate receptor IL-23R is therefore another promising therapeutic strategy for the inhibition of Th17-responses in autoimmunity.

Several antibodies for the application in humans have been developed so far, including the anti-IL-12/23p40 antibodies ustekinumab and briakinumab.

Due to its favorable efficacy, ustekinumab has already been approved for the treatment of psoriasis [93,94], PsA [95-98] and CD (NCT01369329, NCT01369342). Additional clinical trials are underway assessing the effectiveness of ustekinumab in UC (NCT02407236; phase 3), SpA (NCT02437162, NCT02438787, NCT02407223; phase 3), RA (NCT01645280; phase 2) and type 1 diabetes (T1D) (NCT02117765; phase 1 \& 2). Notably, ustekinumab did not reduce disease activity of MS patients, hence no further studies are planned in this area [99]. Briakinumab was associated with an increased risk of major adverse cardiovascular events [100], and its application for marketing approval was therefore withdrawn in 2011.

Several anti-IL-23p19 antibodies (tildrakizumab, guselkumab, BI-655066, AMG 139, LY3074828) have been in clinical development. These antibodies enable specific targeting of IL-23 without the 
cross-reactive effect on IL-12. Tildrakizumab and guselkumab are currently under investigation in phase 3 clinical trials (Tildra: NCT01722331, NCT01729754; Guselku: VOYAGE 1 \& 2) for psoriasis and in a phase 2 study for PsA (Guselku: NCT02319759). BI-655066 induced rapid and durable clinical improvements in psoriasis patients [101] while LY3074828 and AMG139 are still in early stages of studies for psoriasis, $\mathrm{CD}$ and UC.

\subsubsection{IL-6 \& IL-6R}

A substantial role for IL- 6 in modulating the Th17/Treg ratio has become increasingly evident because IL- 6 is essential for Th17-cell differentiation and also inhibits TGF- $\beta$-induced Treg-development [46,49].

Tocilizumab and sarilumab are monoclonal antibodies targeting the human IL-6R. In RA, clinical studies have demonstrated a significant reduction in Th17-cells in tocilizumab-treated patients compared to pre-treatment levels, while at the same time an increase in Tregs was seen [102-104]. Similarly, Tada et al. [105] reported the Foxp3/ROR $\gamma t$ ratio to rise upon tocilizumab treatment in RA patients. An earlier study by Pesce et al. did not observe a significant effect of tocilizumab on Th17 frequencies, whereas Treg numbers increased [106]. Cytokine levels of IL-17A were not affected in tocilizumab-treated RA patients in a recent study by Lee et al. [107]; however, higher baseline IL-17A levels were associated with a worse responsiveness to the treatment. A tempting approach to achieve better treatment outcomes might thus be a combined therapy with IL-17A blockers (e.g., secukinumab) and IL-6-inhibitors such as tocilizumab. This approach, however, has yet to be addressed.

Tocilizumab is meanwhile not only approved for the treatment of RA, but also for polyarticular and systemic JIA due to its favorable results in numerous clinical trials [10,11]. In addition, sarilumab was demonstrated to significantly improve various disease-aspects in RA patients [108-110] but its potential approval for RA is still pending. Notably, sarilumab [111] and tocilizumab (NCT01209702, NCT01209689) both failed to achieve significant benefits in AS patients.

Sirukumab, olokizumab and clazakizumab are therapeutic tools that also interfere with IL-6 signaling, but directly target IL-6 and inhibit its interaction with the IL-6R. Several phase 3 clinical trials are currently assessing sirukumab (NCT02019472, NCT01604343, NCT01606761, NCT01856309, NCT02019472) and olokizumab (NCT02760368, NCT02760433 and NCT02760407) as therapeutic alternatives in RA. Clazakizumab already proved efficacy in phase 2 trials of RA [112] and PsA [113] and it may be expected that this drug becomes approved for the treatment of both diseases if its efficacy can be confirmed in phase 3 trials.

\subsection{Targeting Transcription Factors}

\subsection{1. $\mathrm{ROR} \gamma \mathrm{t}$}

The ROR family of nuclear hormone receptors generally comprises three different members: $\operatorname{ROR} \alpha, \operatorname{ROR} \beta$ and ROR $\gamma$. While ROR $\gamma$ mRNA is present in various peripheral tissues, expression of its isoform ROR $\gamma \mathrm{t}$ is restricted to lymphoid tissues and certain types of lymphoid cells [114]. After ROR $\gamma \mathrm{t}$ was recognized as master transcription factor of the Th17-lineage, there has been a major research interest in potential inhibitors of the ROR $\gamma \mathrm{t} / \mathrm{Th} 17$ axis.

The small molecule digoxin has been well established for decades in cardiology. Later it was reported also to inhibit the transcriptional activity of ROR $\gamma \mathrm{t}$ [115]. Digoxin suppressed differentiation of murine Th17-cells without affecting other T-cell lineages [116] and inhibited IL-17 production of T-cells from EAE mice [115]. Consistently, digoxin was effective in attenuating EAE [116] as well as in reducing the incidence of arthritis and joint inflammation in CIA mice, where it significantly reduced Th17-cells and increased Treg numbers [117].

Another study in the CIA mouse model identified the herbal medicine compound ursolic acid (UA) to effectively inhibit ROR $\gamma \mathrm{t}$ function and to decrease IL-17 expression in developing and differentiated Th17-cells [118]. In the spleens of these animals, UA decreased the frequency of Th17-cells while Treg 
numbers were increased [118]. Clinically UA treatment resulted in a reduction of disease activity of CIA mice [118].

TMP778 and TMP920 were identified as inverse agonists of ROR $\gamma \mathrm{t}$ [119]. Both molecules were shown to potently suppress Th17-cell generation and IL-17 secretion by differentiated Th17-cells in vitro [119]. TMP778 moreover inhibited human Th17 signature gene expression in vitro as well as murine Th17-cell differentiation in vivo [120,121]. Two independent murine studies reported TMP778 administration to reduce imiquimod-induced cutaneous inflammation (a murine model of psoriasis) and the severity of EAE [119,121]. Unfortunately, high doses of digoxin, TMP778 and TMP920 are most likely toxic for a variety of non-immune tissues and cells. Lately, Takaishi et al. [122] described attenuation of psoriasis-like lesions in two independent psoriasis mouse models after oral administration of the novel ROR $\gamma \mathrm{t}$ antagonist A213. They suggested that this effect was based on neutralization of IL-17-producing cells [122], however, A213 also led to a systemic attenuation of Tregs. The underlying mechanism for this effect remained unclear [122]. Smith et al. [123] described the ROR $\gamma t$ inverse agonist GSK2981278 to significantly inhibit production of Th17 signature cytokines (IL-17A, IL-17F, IL-22 and IL-23) in multiple in vitro and human tissue-based assays, including topical delivery of the compound via the sRICA assay and psoriatic lesional explants. Assuming that tissue cytokine production is one of the main drivers of inflammation in plaque psoriasis, this study suggests that topical treatment with GSK2981278 might improve clinical outcomes of psoriasis patients [123]. Results from a recent phase 1 proof-of-concept study (NCT02548052) will shed more light on the potential benefit of topical GSK2981278 application in psoriasis patients. Another inverse agonist, VTP-43742 [124], is already in a phase II clinical trial (NCT02555709).

Given that ROR $\gamma \mathrm{t}$ and ROR $\gamma$ share a similar ligand binding domain (LBD) but differ by a variation in their N-terminal region [114], current small molecule antagonists and inverse agonist targeting ROR $\gamma \mathrm{t}$ bear the risk of an inadvertent impact on non-immune tissues via binding of ROR $\gamma$. The mechanisms of post-translational modification of ROR $\gamma t$, including acetylation and ubiquitinylation, are therefore subject of ongoing investigations with the goal to develop therapeutic ROR $\gamma t$ modulators with greater specificity, selectivity and safety.

The fact that acetylation and ubiquitination processes often compete for the same lysine residues led to speculations about the exact consequences of these modifications in Th17-cells. One hypothesis is that acetylation prevents the respective protein from ubiquitination-induced proteasomal degradation. For instance, histone acetyltransferase (HAT) p300 was shown to stabilize ROR $\gamma \mathrm{t}$ via acetylation of its K81 residue. Knockdown of p300 in HEK293 T-cells resulted in down-regulation of ROR $\gamma \mathrm{t}$ protein levels [125]. However, there is also evidence that this acetylation occurs within the DNA-binding region of ROR $\gamma \mathrm{t}$ consequently impairing interaction of the transcription factor with its target genes [126]. Using mass spectrometry, Lim et al. [126] reported that all three acetylated lysine residues (K69, K81, K99) located within the DNA-binding domain of ROR $\gamma \mathrm{t}$ become deacetylated in presence of the protein deacetylase SIRT1. Hence, SIRT1 increased transcriptional activity of ROR $\gamma t$ and enhanced Th17-cell development and function [126]. SIRT-inhibition in EAE mice not only delayed disease onset, but also ameliorated disease severity. This observation supports the concept of a pro-inflammatory role of SIRT1 in autoimmunity [126].

Apart from acetylation, the complex area of ubiqitination-mediated ROR $\gamma$ t-regulation was recently addressed. Several reports identified a number of E3 ubiquitin ligases (e.g., Itch, UBR5 and TRAF5) that seem to be involved in Th17-regulation by ubiquitination of ROR $\gamma \mathrm{t}$ [127-129]. E3 ligases are known to mediate the last step in the ubiquitination cascade, whereas deubiquitnating enzymes (e.g., USP15, USP17, DUBA) counteract this mechanism. Itch was identified to target ROR $\gamma \mathrm{t}$ for ubiquitination, resulting in decreased IL-17 expression and preventing colonic inflammation [129]. He et al. [130] recently reported that deubiquitination of K446 by ubiquitin-specific protease USP15 enhanced the recruitment of steroid receptor coactivator 1 (SRC1), thereby stimulating ROR $\gamma$ t activity. Moreover, USP17 seems to acts as a positive regulator of ROR $\gamma \mathrm{t}$ [131]. Its knockdown in Th17-cells decreased ROR $\gamma t$ protein levels and expression of Th17-related genes [131]. Paradoxically, TRAF5 
mediated ubiquitination stabilizes $\mathrm{ROR} \gamma \mathrm{t}$ protein levels and might thus aggravate inflammatory responses [127]. Consistent with this observation, elevated TRAF5 mRNA levels were found in CD4+ T-cells from SLE-patients [127]. Another surprising observation is the stabilization of ubiquitin ligase UBR5 upon accumulation of deubiqitinase DUBA in activated T-cells. In response to TGF- $\beta$ singaling, UBR5 could then ubiquitinate the $\mathrm{ROR} \gamma$ protein and act as cell-intrinsic suppressor of IL-17 production [128].

In summary, post-translational modification of ROR $\gamma \mathrm{t}$ is a tightly regulated, highly complex mechanism. Extensive investigational effort is needed in order to identify a safe target for novel pharmacologic interventions in AIDs.

\subsubsection{STAT3}

Differentiation of Th17-cells is triggered by an intracellular signaling cascade involving IL-6-dependent phosphorylation and activation of STAT3 [67,132]. More precisely, binding of IL-6 to its receptor IL-6R results in homodimerization of the signal-transducing $\beta$-receptor gp130 [133]. This leads to STAT3 phosphorylation via activation of gp130-associated janus kinases (JAKs), in particular Jak1 [132]. STAT3 is a latent transcription factor that upon phosphorylation translocates into the nucleus to induce transcription of IL-6-responsive genes [132]. As previously mentioned, IL-6-dependent STAT3 activation downregulates TGF- $\beta$-induced Foxp3-expression and promotes differentiation of naïve CD4+ T-cells into Th17-cells with simultaneous suppression of Treg development [67]. Therapeutic approaches aimed at the modulation of IL-6 signaling are thus not limited to direct targeting of IL-6 and its receptor IL-6R, but also comprise inhibition of the JAK/STAT pathway.

Tofacitinib is a targeted synthetic small molecule that competitively binds to the ATP-binding pocket of JAKs, thus inhibiting their catalytic activity in a reversible manner [134]. Tofacitinib potently inhibited IL-6 induced phosphorylation of STAT1 and STAT3 in human whole blood cellular studies [135] and in synovial tissue extracts from RA patients [136]. Importantly, reduced levels of pSTAT1 and pSTAT3 in synovial biopsies were highly correlated with clinical improvement of RA, indicating that JAK1-mediated signaling of IFNs and IL-6 is involved in the synovial response to JAK blockade [136]. Moreover, tofacitinib potently suppressed the generation of pathogenic Th17-cells with an IL-23/STAT3 signature by abrogating IL-21, IL-22 but also IL-23R expression [137]. Tofacitinib is approved for RA in numerous countries [9], and it is under investigation as a possible treatment option for other inflammatory disorders , including psoriasis [138-140], PsA [141] and IBD [142,143]. The STAT3 inhibitor STA-21 is another compound that interferes with STAT3 signaling leading to an improvement of the clinical course of arthritis in IL-1Ra-KO mice. STA-21 enhanced Treg function and numbers while acting suppressive on Th17-cells and osteoclast formation [144]. SHR0302-another JAK inhibitor-binding JAK1 with strong affinity-reduced Th17 function along with total B-cell numbers via inhibition of JAK1-STAT3 phosphorylation in a study with adjuvant-induced arthritis rats [145]. Human clinical trials for SHR0302 have recently been started with three studies evaluating pharmacokinetics, safety and tolerability in healthy individuals (NCT02892370, NCT02423538) and RA patients (NCT02665910).

Several other biological and synthetic compounds were shown in animal models to skew the Th17/Treg balance towards the regulatory direction by blocking STAT3 phosphorylation. These compounds include the green tea-derived component epigallocatechin-3-gallate (EGCG) [146], the herbal compound celastrol [147], grape seed proanthocyanidin extract (GSPE) [148], the gastrointestinal protective drug rebamipide [149], halofuginone [150] and the antidiabetic drug metformin [151]. Among these, GSPE and metformin were also reported to increase the phosphorylation of STAT5 thus additionally enhancing Treg development [148,151].

\subsubsection{Foxp3}

Targeting the bona fide Treg marker Foxp3 is a reasonable choice to influence the Th17/Treg equilibrium and thus, numerous studies investigated the effect of Foxp3 modulation. Several animal 
studies for example demonstrated that ectopic expression of Foxp3 in conventional T-cells by retroviral gene transfer resulted in a Treg-like phenotype and function and that these Foxp3-transduced T-cells were able to suppress arthritis in a murine host [152-154].

In the absence of IL-6, TGF- $\beta$ stimulates a transcriptional program in naive T-cells with up-regulation of Foxp3 and inhibition of nuclear receptor ROR $\gamma t$, finally resulting in the evolvement of iTregs. Inhibition of ROR $\gamma \mathrm{t}$ by Foxp3, however, is abolished under the influence of TGF- $\beta$ plus IL-6, leading to the generation of Th17-cells [155]. Consequently, tocilizumab treatment was shown to increase the Foxp3/ROR $\gamma t$ ratio in patients with RA [105]. A similar effect was observed in studies evaluating the effect of TNF- $\alpha$ blockade on Foxp3. Etanercept treatment induced transcriptional levels of Foxp3, STAT3 and STAT4 mRNA in responding psoriasis patients [156] and increased the Foxp3/ROR $\gamma$ t ratio in RA patients [157]. In the latter study, the Treg/Th17 ratio negatively correlated with TGF- $\beta$, but positively correlated with IL-6. More recently, adalimumab was reported to expand functional Foxp3+ Tregs via binding monocyte membrane TNF, and it unexpectedly enhanced the expression of TNF-RII on Treg-cells [158].

Abatacept, a CTLA-4 fusion protein, is clinically effective in RA and was recently effective in delaying the decline of beta-cell function in recent-onset T1D $[159,160]$. Tregs stimulated via CTLA-4 showed increased suppressive capacity in vitro, whereas activity of non-regulatory T-cells was reduced upon CTLA-4 ligation [161]. Moreover, abatacept therapy decreased the Foxp3/ROR $\gamma \mathrm{t}$ ratio [105]. In accordance with this finding, Bonelli et al. [162] observed an increase in Foxp3+ Tregs following initiation of CTLA-4Ig treatment. Tregs isolated from these abatacept-treated patients, however, revealed diminished in vitro suppression of responder cell proliferation [162].

In the early phase of B-cell depletion with rituximab, mRNA levels of Foxp3 were significantly increased in patients with active SLE. During follow-up, patients in clinical remission revealed persistently elevated Foxp3 mRNA levels, whereas this marker decreased in patients with active disease [163]. This finding is potentially explained by a simultaneous rise in mRNA levels of TGF- $\beta$, a cytokine contributing to Treg induction.

Apart from the aforementioned factors, epigenetic modifications contribute to the regulation of Foxp3 expression. A critical factor in Foxp3 protein stability is the methylation status of CpG sites within the proximal promoter region of the FOXP3 gene [164]. In vitro experiments showed that TGF- $\beta$ favors de-methylation, whereas the addition of IL-6 increases methylation, the latter resulting in reduced Foxp3 expression [165]. More recently, Cribbs et al. [166] reported that methotrexate was able to increase expression of Foxp3 and restored suppressive function of initially defective Tregs in RA patients. Bisulfite sequencing PCR of methotrexate-treated Tregs revealed a significant reduction in methylation of the FOXP3 upstream enhancer region [166]. Similarly, treatment with the combination rapamycin/IL-2 was shown to augment the frequency and function of Tregs in vitro [167]. The suppressive activity of these Tregs was further increased by all trans retinoic acid, leading to a lower methylation status of the FOXP3 gene [168].

These findings led to the hypothesis that inhibition of DNA methyltransferases (DNMTs) might be a treatment option in autoimmunity. In vitro studies demonstrated the emergence of a stable Foxp3+ Treg population in the presence of TGF- $\beta$ and the DNMT inhibitor 5-aza-20- deoxycytidine [165]. Another method to increase Foxp3 expression in Tregs is the inhibition of histone deacetylases (HDACs). HDACs are normally recruited by methylated DNA and mediate compact nucleosome formation. A study in mice showed that trichostatin A therapy down-regulating HDACs led to increased prevalence and suppressive function of Foxp3+ Tregs [169]. Accordingly, impaired Treg function was observed upon inhibition of acetyltransferase p300, since p300-despite increasing stability of ROR $\gamma \mathrm{t}$ [125] — hyperacetylates Foxp3 [170]. Besides, deletion of HDAC6, HDAC9, or Sirt1 increased expression of the gene encoding Foxp3, and enhanced suppressive function of Tregs [171-173]. On the other hand, Tregs of HDAC5 $5^{-/}$mice showed reduced suppressive function in vitro and in vivo. CD4+ T-cells lacking HDAC5 convert poorly into Tregs despite appropriate polarizing conditions [174]. 
Therefore, there is a need for subsequent studies and a more sophisticated inhibition of HDACs seems necessary to ensure stable Treg induction.

\subsubsection{FoxO1}

Recently, FoxO1 was reported to be a negative regulator of the Th17 transcriptional program [175]. Expression of FoxO1 in T-cells resulted in a distinct reduction in Th17 generation as well as in a lower transcription of IL-17 and IL-23R genes in vitro. At the molecular level, FoxO1 binds ROR $\gamma \mathrm{t}$ via its DNA binding domain thereby inhibiting the activity of this gene. As outlined above, RA patients treated with the anti-IL-6R antibody tocilizumab yielded a marked reduction of circulating Th17-cells and simultaneously an increase of peripheral Tregs [102]. The effect of IL-6 is related, at least partly, to FoxO1. Ichiyama et al. [176] showed that IL-6 induces a microRNA-183-96-182 cluster in Th17-cells. This cluster directly represses FoxO1 which in turn inhibits the expression of IL-1R1 resulting in enhanced pathogenic cytokine production [176]. Another study reported that microRNA 182 inhibits Treg differentiation in a FoxO1 dependent manner [177]. Accumulating evidence suggests that anti-TNF- $\alpha$ therapy may support immunomodulation by Tregs via the influence of this therapy on FoxO1. While TNF- $\alpha$ induced the activation of FoxO1 in human fibroblasts [178], the TNF- $\alpha$ antagonist etanercept was reported to re-activate FoxO1 in patients suffering from psoriasis [179]. Liao et al. [180] reported that TNF- $\alpha$ promotes microRNA-705 expression, which in turn represses FoxO1 via post-transcriptional regulation. Consistently, elevated numbers of Tregs [181] as well as reduced frequencies of Th17-cells $[182,183]$ were described following anti-TNF- $\alpha$ treatment in patients with RA.

FoxO1 is also modulated by environmental factors. Wu et al. reported for example that a modest increase in salt concentration induces SGK1 expression thus deactivating FoxO1 and promoting IL-23R expression and Th17-cell differentiation in mice in vitro and in vivo [65]. Besides, in vitro high-salt activation of human Tregs resulted in the loss of suppressive function that was mediated by FoxO1-dependent alterations in Foxp3 stability [184]. Luo et al. recently reported that differentiation of activated Tregs was associated with repression of FoxO1-dependent gene transcription, along with a reduced FoxO1 expression [185]. This finding indicates that the role of FoxO1 is not fully understood and requires further investigation.

\subsection{Targeting Intracellular Signaling Pathways}

\subsubsection{ROCK Inhibition}

Rho associated kinase 2 (ROCK2) was shown to be activated in murine T-cells under Th17conditions and is thought to influence Th17-generation via phosphorylation of IRF4, a transcription factor involved in the development of Th17-cells [186,187]. Notably, ROCK activity was found to be increased in SLE and RA patients [188,189]. In studies on human T-cells, ROCK2 was reported to control IL-21 and IL-17 secretion via mechanisms that involve regulation through STAT3, IRF4, and ROR $\gamma$ t [190,191]. As reported by Biswas et al. [187] ROCK inhibition diminished production of

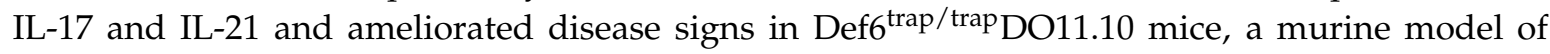
RA-like arthritis. Fasudil derivative FaD-1, a ROCK inhibitor, was reported to ameliorate neurological defects and disease severity in EAE mice, in part via downregulation of the Th17-response in the spinal cord [192]. WAR-5, another ROCK inhibitor described to selectively inhibit ROCK2 led to the attenuation of myelin damage, reduction of CNS inflammation and alleviation of clinical symptoms in EAE mice [193]. WAR-5 treatment further reduced levels of IFN- $\gamma$ and IL-17 while increasing IL-10. This might thus skew the imbalance between Th1/Th17-cells and Tregs in many autoimmune diseases toward immune regulation [193]. Zanin-Zhorov et al. [190] investigated KD025, a selective ROCK2 inhibitor, to modulate inflammation by decreasing STAT3 activation, enhancing STAT5 phosphorylation and increasing the suppressive function of Tregs. Overall, KD025 induced a beneficial shift in the Th17/Treg balance [190]. Two phase 2 clinical trials (NCT02317627 and NCT02106195) 
investigating the efficacy of KD025 for the treatment of psoriasis have recently been completed, the results of these trials will be available soon. Another study with a similar objective (NCT02852967) has just started recruitment and will presumably be completed in 2018.

\subsubsection{MAPK Inhibition}

In contrast to effector T-cells, Tregs constitutively express GITR at a high level [23]. Interestingly, ligation of GITR with its cognate ligand GITRL can abrogate suppressive function of Tregs [194]. The differentiation of naïve CD4+ T-cells was skewed toward the Th17-lineage when cultured with GITRL protein. Besides, the administration of recombinant GITRL resulted in enhanced Th17-cell generation and exacerbation of arthritis in CIA mice [195].

Tang et al. [196] have proposed the molecular mechanism underlying GITRL modulation of Th17-cells to be based on enhanced phosphorylation of p38 MAPK and subsequent phosphorylation of STAT3. Elevated levels of p38 MAPK phosphorylation in RA CD4+ T-cells correlated with increased serum autoantibody levels in these patients [196]. More recently, Li et al. [197] reported that elevated concentrations of GITRL were found in RA synovial fluid and serum, and that GITRL levels correlated with autoantibody production. Notably, administration of a p38 MAPK inhibitor resulted in suppression of GITRL-induced Th17-differentiation and ameliorated disease activity in CIA mice [196]. Unfortunately, several specific pharmacologic inhibitors of p38 MAPK inhibitors were found to be ineffective in clinical studies of RA [198].

\section{Conclusions}

A bulk of evidence has highlighted a shift of the Th17/Treg equilibrium towards the pro-inflammatory Th17-program in several autoimmune disorders, contributing to their progression and recurrent clinical exacerbation. Substantial progress in understanding the development, function and reciprocal regulation of Th17 cells and Tregs yielded a high therapeutic potential for targeting these cell populations. The pathophysiology of autoimmunity however, is complex, explaining the observations that certain therapeutic strategies are effective in some AIDs (e.g., IL-6R blockade in RA [10]), while exhibiting no benefit in others (e.g., IL-6R blockade in AS [111]). Attention must furthermore be drawn to the physiologic role of Th17-cells and -cytokines. For example, IL-17 confers host defense and, in addition to other Th17-cytokines like IL-22, participates in the maintenance of immune homeostasis at mucosal surfaces, especially in the gut [85]. IL-17 neutralization was accompanied by high rates of serious adverse events and fungal infections in CD patients [83,84], despite being highly effective in the treatment of psoriasis [5-8,72]. Recently, it was shown that Th17 is not a uniform subset but rather consists of a non-pathogenic and a pathogenic cell population [61-66]. Targeting pathogenic Th17-cells alone might therefore be the next step to ameliorate Th17/Treg-targeted therapies. Moreover, little is known about the consequences of long-term inhibition of the IL-17 pathway. Various novel candidate molecules to beneficially re-shape the Th17/Treg imbalance have recently shown promising results in animal models [116,118,120,122]. The application of these substances still poses safety issues in humans and requires further evaluation before it can be tested in clinical trials in humans.

In summary, there are still multiple challenges to identify, develop and implement the "ideal" Th17/Treg-targeted interventional strategy with respect to the treatment of autoimmunity.

Author Contributions: P.F. and J.F. wrote the article. M.S., W.G. and C.D. provided intellectual input and critically reviewed the manuscript.

Conflicts of Interest: The authors declare no conflicts of interest. 


\section{References}

1. Grant, C.R.; Liberal, R.; Mieli-Vergani, G.; Vergani, D.; Longhi, M.S. Regulatory T-cells in autoimmune diseases: Challenges, controversies and-Yet-Unanswered questions. Autoimmun. Rev. 2015, 14, 105-116. [CrossRef] [PubMed]

2. Han, L.; Yang, J.; Wang, X.; Li, D.; Lv, L.; Li, B. Th17 cells in autoimmune diseases. Front. Med. 2015, 9, 10-19. [CrossRef] [PubMed]

3. Beringer, A.; Noack, M.; Miossec, P. IL-17 in Chronic Inflammation: From Discovery to Targeting. Trends Mol. Med. 2016, 22, 230-241. [CrossRef] [PubMed]

4. Waite, J.C.; Skokos, D. Th17 response and inflammatory autoimmune diseases. Int. J. Inflam. 2012, 2012, 819467. [CrossRef] [PubMed]

5. Hueber, W.; Patel, D.D.; Dryja, T.; Wright, A.M.; Koroleva, I.; Bruin, G.; Antoni, C.; Draelos, Z.; Gold, M.H.; Group, P.S.; et al. Effects of AIN457, a fully human antibody to interleukin-17A, on psoriasis, rheumatoid arthritis, and uveitis. Sci. Transl. Med. 2010, 2, 52ra72. [CrossRef] [PubMed]

6. Papp, K.A.; Langley, R.G.; Sigurgeirsson, B.; Abe, M.; Baker, D.R.; Konno, P.; Haemmerle, S.; Thurston, H.J.; Papavassilis, C.; Richards, H.B. Efficacy and safety of secukinumab in the treatment of moderate-to-severe plaque psoriasis: A randomized, double-blind, placebo-controlled phase II dose-ranging study. Br. J. Dermatol. 2013, 168, 412-421. [CrossRef] [PubMed]

7. Langley, R.G.; Elewski, B.E.; Lebwohl, M.; Reich, K.; Griffiths, C.E.M.; Papp, K.; Puig, L.; Nakagawa, H.; Spelman, L.; Sigurgeirsson, B.; et al. Secukinumab in plaque psoriasis-Results of two phase 3 trials. N. Engl. J. Med. 2014, 371, 326-338. [CrossRef] [PubMed]

8. Blauvelt, A.; Prinz, J.C.; Gottlieb, A.B.; Kingo, K.; Sofen, H.; Ruer-Mulard, M.; Singh, V.; Pathan, R.; Papavassilis, C.; Cooper, S. Secukinumab administration by pre-filled syringe: Efficacy, safety and usability results from a randomized controlled trial in psoriasis (FEATURE). Br. J. Dermatol. 2015, 172, 484-493. [CrossRef] [PubMed]

9. Wu, P.; Nielsen, T.E.; Clausen, M.H. FDA-approved small-molecule kinase inhibitors. Trends Pharmacol. Sci. 2015, 36, 422-439. [CrossRef] [PubMed]

10. Teitsma, X.M.; Marijnissen, A.K.A.; Bijlsma, J.W.J.; Lafeber, F.P.J.; Jacobs, J.W.G. Tocilizumab as monotherapy or combination therapy for treating active rheumatoid arthritis: A meta-analysis of efficacy and safety reported in randomized controlled trials. Arthritis Res. Ther. 2016, 18, 211. [CrossRef] [PubMed]

11. Turnier, J.L.; Brunner, H.I. Tocilizumab for treating juvenile idiopathic arthritis. Expert Opin. Biol. Ther. 2016, 16, 559-566. [CrossRef] [PubMed]

12. Han, J.; Sun, L.; Fan, X.; Wang, Z.; Cheng, Y.; Zhu, J.; Jin, T. Role of regulatory B cells in neuroimmunologic disorders. J. Neurosci. Res. 2016, 94, 693-701. [CrossRef] [PubMed]

13. Cosmi, L.; Liotta, F.; Lazzeri, E.; Francalanci, M.; Angeli, R.; Mazzinghi, B.; Santarlasci, V.; Manetti, R.; Vanini, V.; Romagnani, P.; et al. Human CD8+CD25+ thymocytes share phenotypic and functional features with CD4+CD25+ regulatory thymocytes. Blood 2003, 102, 4107-4115. [CrossRef] [PubMed]

14. Vignali, D.A.A.; Collison, L.W.; Workman, C.J. How regulatory T cells work. Nat. Rev. Immunol. 2009, 8, 523-532. [CrossRef] [PubMed]

15. Bluestone, J.A.; Abbas, A.K. Natural versus adaptive regulatory T cells. Nat. Rev. Immunol. 2003, 3, $253-257$. [CrossRef] [PubMed]

16. Piccirillo, C.A.; Letterio, J.J.; Thornton, A.M.; McHugh, R.S.; Mamura, M.; Mizuhara, H.; Shevach, E.M. CD4+CD25+ Regulatory T Cells Can Mediate Suppressor Function in the Absence of Transforming Growth Factor $\beta 1$ Production and Responsiveness. J. Exp. Med. 2002, 196, 237-245. [CrossRef] [PubMed]

17. Bacchetta, R.; Barzaghi, F.; Roncarolo, M.-G. From IPEX syndrome to FOXP3 mutation: A lesson on immune dysregulation. Ann. N. Y. Acad. Sci. 2016. [CrossRef] [PubMed]

18. Godfrey, V.L.; Wilkinson, J.E.; Russell, L.B. X-linked lymphoreticular disease in the scurfy (sf) mutant mouse. Am. J. Pathol. 1991, 138, 1379-1387. [PubMed]

19. Williams, L.M.; Rudensky, A.Y. Maintenance of the Foxp3-dependent developmental program in mature regulatory $\mathrm{T}$ cells requires continued expression of Foxp3. Nat. Immunol. 2007, 8, 277-284. [CrossRef] [PubMed]

20. Mahmud, S.A.; Manlove, L.S.; Farrar, M.A. Interleukin-2 and STAT5 in regulatory T cell development and function. JAK-STAT 2013, 2, e23154. [CrossRef] [PubMed] 
21. Takahashi, T.; Tagami, T.; Yamazaki, S.; Uede, T.; Shimizu, J.; Sakaguchi, N.; Mak, T.W.; Sakaguchi, S. Immunologic self-tolerance maintained by CD25(+)CD4(+) regulatory $\mathrm{T}$ cells constitutively expressing cytotoxic T lymphocyte-associated antigen 4. J. Exp. Med. 2000, 192, 303-309. [CrossRef] [PubMed]

22. Hamann, A.; Klugewitz, K.; Austrup, F.; Jablonski-Westrich, D. Activation induces rapid and profound alterations in the trafficking of T cells. Eur. J. Immunol. 2000, 30, 3207-3218. [CrossRef]

23. De Boer, O.J.; van der Loos, C.M.; Teeling, P.; van der Wal, A.C.; Teunissen, M.B. Immunohistochemical Analysis of Regulatory T Cell Markers FOXP3 and GITR on CD4+CD25+ T Cells in Normal Skin and Inflammatory Dermatoses. J. Histochem. Cytochem. 2007, 55, 891-898. [CrossRef] [PubMed]

24. Raimondi, G.; Shufesky, W.J.; Tokita, D.; Morelli, A.E.; Thomson, A.W.; Raimondi, G.; Shufesky, W.J.; Tokita, D.; Morelli, A.E.; Thomson, A.W. Regulated compartmentalization of programmed cell death-1 discriminates CD4+CD25+ resting regulatory T cells from activated T cells. J. Immunol. 2006, 176, 2808-2816. [CrossRef] [PubMed]

25. Garcia Santana, C.A.; Tung, J.W.; Gulnik, S. Human Treg cells are characterized by low/negative CD6 expression. Cytom. A 2014, 85, 901-908. [CrossRef] [PubMed]

26. Salgado, F.J.; Pérez-Díaz, A.; Villanueva, N.M.; Lamas, O.; Arias, P.; Nogueira, M. CD26: A negative selection marker for human Treg cells. Cytom. A 2012, 81, 843-855. [CrossRef] [PubMed]

27. Kleinewietfeld, M.; Starke, M.; Di Mitri, D.; Borsellino, G.; Battistini, L.; Rötzschke, O.; Falk, K. CD49d provides access to "untouched" human Foxp3+ Treg free of contaminating effector cells. Blood 2009, 113, 827-836. [CrossRef] [PubMed]

28. Shen, L.S.; Wang, J.; Shen, D.F.; Yuan, X.L.; Dong, P.; Li, M.X.; Xue, J.; Zhang, F.M.; Ge, H.L.; Xu, D. CD4+CD25+CD127low/- regulatory T cells express Foxp3 and suppress effector T cell proliferation and contribute to gastric cancers progression. Clin. Immunol. 2009, 131, 109-118. [CrossRef] [PubMed]

29. Hartigan-O'Connor, D.J.; Poon, C.; Sinclair, E.; McCune, J.M. Human CD4+ regulatory T cells express lower levels of the IL-7 receptor alpha chain (CD127), allowing consistent identification and sorting of live cells. J. Immunol. Methods 2007, 319, 41-52. [CrossRef] [PubMed]

30. Li, M.O.; Sanjabi, S.; Flavell, R.A. Transforming Growth Factor- $\beta$ Controls Development, Homeostasis, and Tolerance of T Cells by Regulatory T Cell-Dependent and -Independent Mechanisms. Immunity 2006, 25, 455-471. [CrossRef] [PubMed]

31. Marie, J.C.; Liggitt, D.; Rudensky, A.Y. Cellular Mechanisms of Fatal Early-Onset Autoimmunity in Mice with the T Cell-Specific Targeting of Transforming Growth Factor- $\beta$ Receptor. Immunity 2006, 25, 441-454. [CrossRef] [PubMed]

32. Li, M.O.; Flavell, R.A. Contextual Regulation of Inflammation: A Duet by Transforming Growth Factor- $\beta$ and Interleukin-10. Immunity 2008, 28, 468-476. [CrossRef] [PubMed]

33. Li, M.O.; Flavell, R.A. TGF- $\beta$ : A Master of All T Cell Trades. Cell 2008, 134, 392-404. [CrossRef]

34. Rubtsov, Y.P.; Rasmussen, J.P.; Chi, E.Y.; Fontenot, J.; Castelli, L.; Ye, X.; Treuting, P.; Siewe, L.; Roers, A.; Henderson, W.R.; et al. Regulatory T Cell-Derived Interleukin-10 Limits Inflammation at Environmental Interfaces. Immunity 2008, 28, 546-558. [CrossRef] [PubMed]

35. Chaudhry, A.; Samstein, R.M.; Treuting, P.; Liang, Y.; Pils, M.C.; Heinrich, J.M.; Jack, R.S.; Wunderlich, F.T.; Brüning, J.C.; Müller, W.; et al. Interleukin-10 Signaling in Regulatory T Cells Is Required for Suppression of Th17 Cell-Mediated Inflammation. Immunity 2011, 34, 566-578. [CrossRef] [PubMed]

36. Huber, S.; Gagliani, N.; Esplugues, E.; O'Connor, W.; Huber, F.J.; Chaudhry, A.; Kamanaka, M.; Kobayashi, Y.; Booth, C.J.; Rudensky, A.Y.; et al. Th17 Cells Express Interleukin-10 Receptor and Are Controlled by Foxp3and Foxp3+ Regulatory CD4+ T Cells in an Interleukin-10-Dependent Manner. Immunity 2011, 34, 554-565. [CrossRef] [PubMed]

37. Wadwa, M.; Klopfleisch, R.; Adamczyk, A.; Frede, A.; Pastille, E.; Mahnke, K.; Hansen, W.; Geffers, R.; Lang, K.S.; Buer, J.; et al. IL-10 downregulates CXCR3 expression on Th1 cells and interferes with their migration to intestinal inflammatory sites. Mucosal Immunol. 2016, 9, 1263-1277. [CrossRef] [PubMed]

38. Murai, M.; Turovskaya, O.; Kim, G.; Madan, R.; Karp, C.L.; Kronenberg, M. Interleukin 10 acts on regulatory $\mathrm{T}$ cells to maintain expression of the transcription factor Foxp3 and suppressive function in mice with colitis. Nat. Immunol. 2009, 10, 1178-1184. [CrossRef] [PubMed]

39. Collison, L.W.; Chaturvedi, V.; Henderson, A.L.; Giacomin, P.R.; Guy, C.; Bankoti, J.; Finkelstein, D.; Forbes, K.; Workman, C.J.; Brown, S.A.; et al. IL-35-mediated induction of a potent regulatory $\mathrm{T}$ cell population. Nat. Immunol. 2010, 11, 1093-1101. [CrossRef] [PubMed] 
40. Collison, L.W.; Workman, C.J.; Kuo, T.T.; Boyd, K.; Wang, Y.; Vignali, K.M.; Cross, R.; Sehy, D.; Blumberg, R.S.; Vignali, D.A.A. The inhibitory cytokine IL-35 contributes to regulatory T-cell function. Nature 2007, 450, 566-569. [CrossRef] [PubMed]

41. Wirtz, S.; Billmeier, U.; Mcheldlidze, T.; Blumberg, R.S.; Neurath, M.F. Interleukin-35 Mediates Mucosal Immune Responses That Protect Against T-Cell-Dependent Colitis. Gastroenterology 2011, 141, 1875-1886. [CrossRef] [PubMed]

42. Harrington, L.E.; Hatton, R.D.; Mangan, P.R.; Turner, H.; Murphy, T.L.; Murphy, K.M.; Weaver, C.T. Interleukin 17-producing CD4+ effector T cells develop via a lineage distinct from the T helper type 1 and 2 lineages. Nat. Immunol. 2005, 6, 1123-1132. [CrossRef] [PubMed]

43. Park, H.; Li, Z.; Yang, X.O.; Chang, S.H.; Nurieva, R.; Wang, Y.; Wang, Y.; Hood, L.; Zhu, Z.; Tian, Q.; et al. A distinct lineage of CD4 T cells regulates tissue inflammation by producing interleukin 17. Nat. Immunol. 2005, 6, 1133-1141. [CrossRef] [PubMed]

44. Bettelli, E.; Korn, T.; Oukka, M.; Kuchroo, V.K. Induction and effector functions of T(H)17 cells. Nature 2008, 453, 1051-1057. [CrossRef] [PubMed]

45. Torchinsky, M.B.; Blander, J.M. T helper 17 cells: Discovery, function, and physiological trigger. Cell. Mol. Life Sci. 2010, 67, 1407-1421. [CrossRef] [PubMed]

46. Bettelli, E.; Carrier, Y.; Gao, W.; Korn, T.; Strom, T.B.; Oukka, M.; Weiner, H.L.; Kuchroo, V.K. Reciprocal developmental pathways for the generation of pathogenic effector TH17 and regulatory T cells. Nature 2006, 441, 235-238. [CrossRef] [PubMed]

47. Manel, N.; Unutmaz, D.; Littman, D.R. The differentiation of human Th-17 cells requires transforming growth factor- $\beta$ and induction of the nuclear receptor ROR $\gamma$ T. Nat. Immunol. 2008, 9, 641-649. [CrossRef] [PubMed]

48. Ichiyama, K.; Yoshida, H.; Wakabayashi, Y.; Chinen, T.; Saeki, K.; Nakaya, M.; Takaesu, G.; Hori, S.; Yoshimura, A.; Kobayashi, T. Foxp3 Inhibits ROR $\gamma$ t-mediated IL-17A mRNA Transcription through Direct Interaction with ROR $\gamma$ t. J. Biol. Chem. 2008, 283, 17003-17008. [CrossRef] [PubMed]

49. Korn, T.; Bettelli, E.; Gao, W.; Awasthi, A.; Jager, A.; Strom, T.B.; Oukka, M.; Kuchroo, V.K. IL-21 initiates an alternative pathway to induce proinflammatory T(H)17 cells. Nature 2007, 448, 484-487. [CrossRef] [PubMed]

50. Ivanov, I.I.; Zhou, L.; Littman, D.R. Transcriptional regulation of Th17 cell differentiation. Semin. Immunol. 2007, 19, 409-417. [CrossRef] [PubMed]

51. Wilson, N.J.; Boniface, K.; Chan, J.R.; McKenzie, B.S.; Blumenschein, W.M.; Mattson, J.D.; Basham, B.; Smith, K.; Chen, T.; Morel, F.; et al. Development, cytokine profile and function of human interleukin 17-producing helper T cells. Nat. Immunol. 2007, 8, 950-957. [CrossRef] [PubMed]

52. Acosta-Rodriguez, E.V.; Rivino, L.; Geginat, J.; Jarrossay, D.; Gattorno, M.; Lanzavecchia, A.; Sallusto, F.; Napolitani, G. Surface phenotype and antigenic specificity of human interleukin 17-producing T helper memory cells. Nat. Immunol. 2007, 8, 639-646. [CrossRef] [PubMed]

53. Maggi, L.; Santarlasci, V.; Capone, M.; Peired, A.; Frosali, F.; Crome, S.Q.; Querci, V.; Fambrini, M.; Liotta, F.; Levings, M.K.; et al. CD161 is a marker of all human IL-17-producing T-cell subsets and is induced by RORC. Eur. J. Immunol. 2010, 40, 2174-2181. [CrossRef] [PubMed]

54. Annunziato, F.; Cosmi, L.; Liotta, F.; Maggi, E.; Romagnani, S. Defining the human T helper 17 cell phenotype. Trends Immunol. 2012, 33, 505-512. [CrossRef] [PubMed]

55. Pelletier, M.; Maggi, L.; Micheletti, A.; Lazzeri, E.; Tamassia, N.; Cosmi, L.; Lunardi, C.; Annunziato, F.; Romagnani, S.; Marco, A.; et al. Evidence for a cross-talk between human neutrophils and Th17 cells Evidence for a cross-talk between human neutrophils and Th17 cells. Blood 2010, 115, 335-343. [CrossRef] [PubMed]

56. Yang, L.; Anderson, D.E.; Baecher-Allan, C.; Hastings, W.D.; Bettelli, E.; Oukka, M.; Kuchroo, V.K.; Hafler, D.A. IL-21 and TGF- $\beta$ are required for differentiation of human TH17 cells. Nature 2008, 454, 350-352. [CrossRef] [PubMed]

57. Nurieva, R.; Yang, X.O.; Martinez, G.; Zhang, Y.; Panopoulos, A.D.; Ma, L.; Schluns, K.; Tian, Q.; Watowich, S.S.; Jetten, A.M.; et al. Essential autocrine regulation by IL-21 in the generation of inflammatory T cells. Nature 2007, 448, 480-483. [CrossRef] [PubMed]

58. Rutz, S.; Eidenschenk, C.; Ouyang, W. IL-22, not simply a Th17 cytokine. Immunol. Rev. 2013, 252, $116-132$. [CrossRef] [PubMed] 
59. Xie, Q.; Wang, S.C.; Li, J. Interleukin 22, a potential therapeutic target for rheumatoid arthritis. J. Rheumatol. 2012, 39, 2220-2221. [CrossRef] [PubMed]

60. Stephen-Victor, E.; Fickenscher, H.; Bayry, J. IL-26: An Emerging Proinflammatory Member of the IL-10 Cytokine Family with Multifaceted Actions in Antiviral, Antimicrobial, and Autoimmune Responses. PLoS Pathog. 2016, 12, 4-9. [CrossRef] [PubMed]

61. McGeachy, M.J.; Bak-Jensen, K.S.; Chen, Y.; Tato, C.M.; Blumenschein, W.; McClanahan, T.; Cua, D.J. TGF-beta and IL- 6 drive the production of IL-17 and IL-10 by T cells and restrain Th-17 cell-mediated pathology. Nat. Immunol. 2007, 8, 1390-1397. [CrossRef] [PubMed]

62. Ghoreschi, K.; Laurence, A.; Yang, X.; Tato, C.M.; Mandy, J.; Konkel, J.; Ramos, H.L.; Wei, L.; Davidson, T.; Grainger, J.; et al. Generation of Pathogenic Th17 Cells in the Absence of TGF- $\beta$ Signaling. Nature 2010, 467, 967-971. [CrossRef] [PubMed]

63. Chung, Y.; Chang, S.H.; Martinez, G.J.; Yang, X.O.; Kang, H.S.; Ma, L.; Watowich, S.S.; Jetten, A.; Tian, Q.; Dong, C. Critical regulation of early Th17 cell differentiation by IL-1 signaling. Immunity 2009, 30, 576-587. [CrossRef] [PubMed]

64. Lee, Y.; Awasthi, A.; Yosef, N.; Quintana, F.J.; Xiao, S. Induction and molecular signature of pathogenic TH17 cells. Nat. Immunol. 2012, 13, 991-999. [CrossRef] [PubMed]

65. Wu, C.; Yosef, N.; Thalhamer, T.; Zhu, C.; Xiao, S.; Regev, A.; Kuchroo, V. Induction of pathogenic TH17 cells by inducible salt-sensing kinase SGK1. Nature 2013, 496, 513-517. [CrossRef] [PubMed]

66. Wang, C.; Yosef, N.; Gaublomme, J.; Wu, C.; Lee, Y.; Clish, C.B.; Kaminski, J.; Xiao, S.; Zu Horste, G.M.; Pawlak, M.; et al. CD5L/AIM Regulates Lipid Biosynthesis and Restrains Th17 Cell Pathogenicity. Cell 2015, 163, 1413-1427. [CrossRef] [PubMed]

67. Yang, X.O.; Nurieva, R.; Martinez, G.J.; Kang, H.S.; Pappu, B.P.; Shah, B.; Chang, S.H.; Schluns, K.S.; Watowich, S.S.; Feng, X.; et al. Molecular antagonism and plasticity of regulatory and inflammatory T cell programs. Immunity 2008, 29, 44-56. [CrossRef] [PubMed]

68. Deknuydt, F.; Bioley, G.; Valmori, D.; Ayyoub, M. IL-1 $\beta$ and IL-2 convert human Treg into TH17 cells. Clin. Immunol. 2009, 131, 298-307. [CrossRef] [PubMed]

69. Zheng, S.G.; Wang, J.; Horwitz, D.A. Cutting Edge: Foxp3+CD4+CD25+ Regulatory T Cells Induced by IL-2 and TGF- $\beta$ Are Resistant to Th17 Conversion by IL-6. J. Immunol. 2008, 180, 7112-7116. [CrossRef] [PubMed]

70. Komatsu, N.; Okamoto, K.; Sawa, S.; Nakashima, T.; Oh-hora, M.; Kodama, T.; Tanaka, S.; Bluestone, J.A.; Takayanagi, H. Pathogenic conversion of Foxp3+ T cells into TH17 cells in autoimmune arthritis. Nat. Med. 2014, 20, 62-68. [CrossRef] [PubMed]

71. Gagliani, N.; Vesely, M.C.A.; Iseppon, A.; Brockmann, L.; Xu, H.; Palm, N.W.; de Zoete, M.R.; Licona-Limón, P.; Paiva, R.S.; Ching, T.; et al. Th17 cells transdifferentiate into regulatory T cells during resolution of inflammation. Nature 2015, 523, 221-225. [CrossRef] [PubMed]

72. Farahnik, B.; Beroukhim, K.; Abrouk, M.; Nakamura, M.; Zhu, T.H.; Singh, R.; Lee, K.; Bhutani, T.; Koo, J. Brodalumab for the Treatment of Psoriasis: A Review of Phase III Trials. Dermatol. Ther. (Heidelb.) 2016, 6, 111-124. [CrossRef] [PubMed]

73. McInnes, I.B.; Mease, P.J.; Kirkham, B.; Kavanaugh, A.; Ritchlin, C.T.; Rahman, P.; Van Der Heijde, D.; Landewe, R.; Conaghan, P.G.; Gottlieb, A.B.; et al. Secukinumab, a human anti-interleukin-17A monoclonal antibody, in patients with psoriatic arthritis (FUTURE 2): A randomised, double-blind, placebo-controlled, phase 3 trial. Lancet 2015, 386, 1137-1146. [CrossRef]

74. Mease, P.J.; McInnes, I.B.; Kirkham, B.; Kavanaugh, A.; Rahman, P.; van der Heijde, D.; Landewé, R.; Nash, P.; Pricop, L.; Yuan, J.; et al. Secukinumab Inhibition of Interleukin-17A in Patients with Psoriatic Arthritis. N. Engl. J. Med. 2015, 373, 1329-1339. [CrossRef] [PubMed]

75. Baeten, D.; Sieper, J.; Braun, J.; Baraliakos, X.; Dougados, M.; Emery, P.; Deodhar, A.; Porter, B.; Martin, R.; Andersson, M.; et al. Secukinumab, an Interleukin-17A Inhibitor, in Ankylosing Spondylitis. N. Engl. J. Med. 2015, 373, 2534-2548. [CrossRef] [PubMed]

76. Baeten, D.; Baraliakos, X.; Braun, J.; Sieper, J.; Emery, P.; van der Heijde, D.; McInnes, I.; van Laar, J.M.; Landewé, R.; Wordsworth, P.; et al. Anti-interleukin-17A monoclonal antibody secukinumab in treatment of ankylosing spondylitis: A randomised, double-blind, placebo-controlled trial. Lancet 2013, 382, 1705-1713. [CrossRef] 
77. Burmester, G.R.; Durez, P.; Shestakova, G.; Genovese, M.C.; Schulze-Koops, H.; Li, Y.; Wang, Y.A.; Lewitzky, S.; Koroleva, I.; Berneis, A.A.; et al. Association of HLA-DRB1 alleles with clinical responses to the anti-interleukin-17A monoclonal antibody secukinumab in active rheumatoid arthritis. Rheumatology 2016, 55, 49-55. [CrossRef] [PubMed]

78. Genovese, M.C.; Durez, P.; Richards, H.B.; Supronik, J.; Dokoupilova, E.; Aelion, J.A.; Lee, S.-H.; Codding, C.E.; Kellner, H.; Ikawa, T.; et al. One-year Efficacy and Safety Results of Secukinumab in Patients With Rheumatoid Arthritis: Phase II, Dose-finding, Double-blind, Randomized, Placebo-controlled Study. J. Rheumatol. 2014, 41, 414-421. [CrossRef] [PubMed]

79. Genovese, M.C.; Greenwald, M.; Cho, C.-S.; Berman, A.; Jin, L.; Cameron, G.S.; Benichou, O.; Xie, L.; Braun, D.; Berclaz, P.-Y.; et al. A Phase II Randomized Study of Subcutaneous Ixekizumab, an Anti-Interleukin-17 Monoclonal Antibody, in Rheumatoid Arthritis Patients Who Were Naive to Biologic Agents or Had an Inadequate Response to Tumor Necrosis Factor Inhibitors. Arthritis Rheumatol. 2014, 66, 1693-1704. [CrossRef] [PubMed]

80. Martin, D.A.; Churchill, M.; Flores-Suarez, L.; Cardiel, M.H.; Wallace, D.; Martin, R.; Phillips, K.; Kaine, J.L.; Dong, H.; Salinger, D.; et al. A phase Ib multiple ascending dose study evaluating safety, pharmacokinetics, and early clinical response of brodalumab, a human anti-IL-17R antibody, in methotrexate-resistant rheumatoid arthritis. Arthritis Res. Ther. 2013, 15, R164. [CrossRef] [PubMed]

81. Genovese, M.C.; Durez, P.; Richards, H.B.; Supronik, J.; Dokoupilova, E.; Mazurov, V.; Aelion, J.A.; Lee, S.-H.; Codding, C.E.; Kellner, H.; et al. Efficacy and safety of secukinumab in patients with rheumatoid arthritis: A phase II, dose-finding, double-blind, randomised, placebo controlled study. Ann. Rheum. Dis. 2013, 72, 863-869. [CrossRef] [PubMed]

82. Pavelka, K.; Chon, Y.; Newmark, R.; Lin, S.-L.; Baumgartner, S.; Erondu, N. A Study to Evaluate the Safety, Tolerability, and Efficacy of Brodalumab in Subjects with Rheumatoid Arthritis and an Inadequate Response to Methotrexate. J. Rheumatol. 2015, 42, 912-919. [CrossRef] [PubMed]

83. Targan, S.R.; Feagan, B.G.; Vermeire, S.; Panaccione, R.; Melmed, G.Y.; Blosch, C.; Newmark, R.; Zhang, N.; Chon, Y.; Lin, S.-L.; et al. A randomized, double-blind, placebo-controlled study to evaluate the safety, tolerability, and efficacy of AMG 827 in subjects with moderate to severe crohn's disease. Gastroenterology 2012, 143, e26. [CrossRef]

84. Hueber, W.; Sands, B.E.; Lewitzky, S.; Vandemeulebroecke, M.; Reinisch, W.; Higgins, P.D.R.; Wehkamp, J.; Feagan, B.G.; Yao, M.D.; Karczewski, M.; et al. Secukinumab, a human anti-IL-17A monoclonal antibody, for moderate to severe Crohn's disease: Unexpected results of a randomised, double-blind placebo-controlled trial. Gut 2012, 61, 1693-1700. [CrossRef] [PubMed]

85. O'Connor, W., Jr.; Zenewicz, L.A.; Flavell, R.A. The dual nature of T(H)17 cells: Shifting the focus to function. Nat. Immunol. 2010, 11, 471-476. [CrossRef] [PubMed]

86. Langrish, C.L.; Chen, Y.; Blumenschein, W.M.; Mattson, J.; Basham, B.; Sedgwick, J.D.; McClanahan, T.; Kastelein, R.A.; Cua, D.J. IL-23 drives a pathogenic T cell population that induces autoimmune inflammation. J. Exp. Med. 2005, 201, 233-240. [CrossRef] [PubMed]

87. Lee, Y.; Kuchroo, V. Defining the functional states of Th17 cells. F1000Research 2015, 4, 1-7. [CrossRef] [PubMed]

88. Fitch, E.; Harper, E.; Skorcheva, I.; Kurtz, S.E.; Blauvelt, A. Pathophysiology of psoriasis: Recent advances on IL-23 and Th17 cytokines. Curr. Rheumatol. Rep. 2010, 9, 461-467. [CrossRef]

89. Lee, E.; Trepicchio, W.L.; Oestreicher, J.L.; Pittman, D.; Wang, F.; Chamian, F.; Dhodapkar, M.; Krueger, J.G. Increased expression of interleukin 23 p19 and p40 in lesional skin of patients with psoriasis vulgaris. J. Exp. Med. 2004, 199, 125-130. [CrossRef] [PubMed]

90. Cua, D.J.; Sherlock, J.; Chen, Y.; Murphy, C.A.; Joyce, B.; Seymour, B.; Lucian, L.; To, W.; Kwan, S.; Churakova, T.; et al. Interleukin-23 rather than interleukin-12 is the critical cytokine for autoimmune inflammation of the brain. Nature 2003, 421, 744-748. [CrossRef] [PubMed]

91. Murphy, C.A.; Langrish, C.L.; Chen, Y.; Blumenschein, W.; McClanahan, T.; Kastelein, R.A.; Sedgwick, J.D.; Cua, D.J. Divergent pro- and antiinflammatory roles for IL-23 and IL-12 in joint autoimmune inflammation. J. Exp. Med. 2003, 198, 1951-1957. [CrossRef] [PubMed]

92. Nakajima, K.; Kanda, T.; Takaishi, M.; Shiga, T.; Miyoshi, K.; Nakajima, H.; Kamijima, R.; Tarutani, M.; Benson, J.M.; Elloso, M.M.; et al. Distinct roles of IL-23 and IL-17 in the development of psoriasis-like lesions in a mouse model. J. Immunol. Res. 2011, 186, 4481-4489. 
93. Leonardi, C.L.; Kimball, A.B.; Papp, K.A.; Yeilding, N.; Guzzo, C.; Wang, Y.; Li, S.; Dooley, L.T.; Gordon, K.B. Efficacy and safety of ustekinumab, a human interleukin-12/23 monoclonal antibody, in patients with psoriasis: 76-week results from a randomised, double-blind, placebo-controlled trial (PHOENIX 1). Lancet 2008, 371, 1665-1674. [CrossRef]

94. Papp, K.A.; Langley, R.G.; Lebwohl, M.; Krueger, G.G.; Szapary, P.; Yeilding, N.; Guzzo, C.; Hsu, M. Efficacy and safety of ustekinumab, a human interleukin-12/23 monoclonal antibody, in patients with psoriasis: 52-week results from a randomised, double-blind, placebo-controlled trial (PHOENIX 2). Lancet 2008, 371, 1675-1684. [CrossRef]

95. Mcinnes, I.B.; Kavanaugh, A.; Gottlieb, A.B.; Puig, L.; Rahman, P.; Ritchlin, C.; Brodmerkel, C.; Li, S.; Wang, Y. Efficacy and safety of ustekinumab in patients with active psoriatic arthritis: 1 year results of the phase 3 , multicentre, double-blind, placebo-controlled PSUMMIT 1 trial. Lancet 2013, 382, 780-789. [CrossRef]

96. Kavanaugh, A.; Ritchlin, C.; Rahman, P.; Puig, L.; Gottlieb, A.B.; Li, S.; Wang, Y.; Noonan, L.; Brodmerkel, C.; Song, M.; et al. Ustekinumab, an anti-IL-12/23 p40 monoclonal antibody, inhibits radiographic progression in patients with active psoriatic arthritis: Results of an integrated analysis of radiographic data from the phase 3, multicentre, randomised, double-blind, placebo-c. Ann. Rheum. Dis. 2014, 73, 1000-1006. [CrossRef] [PubMed]

97. Kavanaugh, A.; Puig, L.; Gottlieb, A.B.; Ritchlin, C.; You, Y.; Li, S.; Song, M.; Randazzo, B.; Rahman, P.; Mcinnes, I.B. Efficacy and safety of ustekinumab in psoriatic arthritis patients with peripheral arthritis and physician-reported spondylitis: Post-hoc analyses from two phase III, multicentre, double-blind, placebo-controlled studies (PSUMMIT-1/PSUMMIT-2). Ann. Rheum. Dis. 2016, 75, 1984-1988. [CrossRef] [PubMed]

98. Ritchlin, C.; Rahman, P.; Kavanaugh, A.; Mcinnes, I.B.; Puig, L.; Li, S.; Wang, Y.; Shen, Y.; Doyle, M.K.; Mendelsohn, A.M.; et al. Efficacy and safety of the anti-IL-12/23 p40 monoclonal antibody, ustekinumab, in patients with active psoriatic arthritis despite conventional non-biological and biological anti-tumour necrosis factor therapy: 6-month and 1-year results of the controlled. Ann. Rheum. Dis. 2014, 73, 990-999. [CrossRef] [PubMed]

99. Segal, B.M.; Constantinescu, C.S.; Raychaudhuri, A.; Kim, L.; Fidelus-Gort, R.; Kasper, L.H. Repeated subcutaneous injections of IL12/23 p40 neutralising antibody, ustekinumab, in patients with relapsing-remitting multiple sclerosis: A phase II, double-blind, placebo-controlled, randomised, dose-ranging study. Lancet 2008, 7, 796-804. [CrossRef]

100. Gordon, K.B.; Langley, R.G.; Gottlieb, A.B.; Papp, K.A.; Krueger, G.G.; Strober, B.E.; Williams, D.A.; Gu, Y.; Valdes, J.M. A phase III, randomized, controlled trial of the fully human IL-12/23 mAb briakinumab in moderate-to-severe psoriasis. J. Investig. Dermatol. 2012, 132, 304-314. [CrossRef] [PubMed]

101. Krueger, J.G.; Ferris, L.K.; Menter, A.; Wagner, F.; White, A.; Visvanathan, S.; Lalovic, B.; Aslanyan, S.; Wang, E.E.L.; Hall, D.; et al. Anti-IL-23A mAb BI 655066 for treatment of moderate-to-severe psoriasis: Safety, efficacy, pharmacokinetics, and biomarker results of a single-rising-dose, randomized, double-blind, placebo-controlled trial. J. Allergy Clin. Immunol. 2015, 136, 116-124. [CrossRef] [PubMed]

102. Samson, M.; Audia, S.; Janikashvili, N.; Ciudad, M.; Trad, M.; Fraszczak, J.; Ornetti, P.; Maillefert, J.F.; Miossec, P.; Bonnotte, B. Brief report: Inhibition of interleukin-6 function corrects Th17/Treg cell imbalance in patients with rheumatoid arthritis. Arthritis Rheum. 2012, 64, 2499-2503. [CrossRef] [PubMed]

103. Kikuchi, J.; Hashizume, M.; Kaneko, Y.; Yoshimoto, K.; Nishina, N.; Takeuchi, T. Peripheral blood $\mathrm{CD} 4+\mathrm{CD} 25+\mathrm{CD} 127$ low regulatory $\mathrm{T}$ cells are significantly increased by tocilizumab treatment in patients with rheumatoid arthritis: Increase in regulatory $\mathrm{T}$ cells correlates with clinical response. Arthritis Res. Ther. 2015, 17, 1-10. [CrossRef] [PubMed]

104. Li, S.; Wu, Z.; Li, L.; Liu, X. Interleukin-6 (IL-6) Receptor Antagonist Protects Against Rheumatoid Arthritis. Med. Sci. Monit. 2016, 22, 2113-2118. [CrossRef] [PubMed]

105. Tada, Y.; Ono, N.; Suematsu, R.; Tashiro, S.; Sadanaga, Y.; Tokuda, Y.; Ono, Y.; Nakao, Y.; Maruyama, A.; Ohta, A.; et al. The balance between Foxp3 and Ror- $\gamma$ t expression in peripheral blood is altered by tocilizumab and abatacept in patients with rheumatoid arthritis. BMC Musculoskelet. Disord. 2016, 17, 290. [CrossRef] [PubMed] 
106. Pesce, B.; Soto, L.; Sabugo, F.; Wurmann, P.; Cuchacovich, M.; López, M.N.; Sotelo, P.H.; Molina, M.C.; Aguillón, J.C.; Catalán, D. Effect of interleukin-6 receptor blockade on the balance between regulatory T cells and $\mathrm{T}$ helper type 17 cells in rheumatoid arthritis patients. Clin. Exp. Immunol. 2013, 171, 237-242. [CrossRef] [PubMed]

107. Lee, S.J.; Park, W.; Park, S.H.; Shim, S.C.; Baek, H.J.; Yoo, D.H.; Kim, H.A.; Lee, S.K.; Leee, Y.J.; Park, Y.E.; et al. Low baseline interleukin-17A levels are associated with better treatment response at 12 weeks to tocilizumab therapy in rheumatoid arthritis patients. J. Immunol. Res. 2015, 2015, 487230. [CrossRef] [PubMed]

108. Strand, V.; Kosinski, M.; Chen, C.; Joseph, G.; Rendas-baum, R.; Graham, N.M.H.; Van Hoogstraten, H.; Bayliss, M.; Fan, C.; Huizinga, T.; et al. Sarilumab plus methotrexate improves patient-reported outcomes in patients with active rheumatoid arthritis and inadequate responses to methotrexate: Results of a phase III trial. Arthritis Res. Ther. 2016, 18,1-10. [CrossRef] [PubMed]

109. Genovese, M.C.; Fleischmann, R.; Kivitz, A.J.; Rell-Bakalarska, M.; Martincova, R.; Fiore, S.; Rohane, P.; Van Hoogstraten, H.; Garg, A.; Fan, C.; et al. Sarilumab Plus Methotrexate in Patients with Active Rheumatoid Arthritis and Inadequate Response to Methotrexate. Results of a Phase III Study. Arthritis Rheumatol. 2015, 67, 1424-1437. [CrossRef] [PubMed]

110. Boyapati, A.; Msihid, J.; Fiore, S.; van Adelsberg, J.; Graham, N.M.H.; Hamilton, J.D. Sarilumab plus methotrexate suppresses circulating biomarkers of bone resorption and synovial damage in patients with rheumatoid arthritis and inadequate response to methotrexate: A biomarker study of MOBILITY. Arthritis Res. Ther. 2016, 18, 225. [CrossRef] [PubMed]

111. Sieper, J.; Braun, J.; Kay, J.; Badalamenti, S.; Radin, A.R.; Jiao, L.; Fiore, S.; Momtahen, T.; Yancopoulos, G.D.; Stahl, N.; et al. Sarilumab for the treatment of ankylosing spondylitis: Results of a Phase II, randomised, double-blind, placebo-controlled study (ALIGN). Ann. Rheum. Dis. 2015, 74, 1051-1057. [CrossRef] [PubMed]

112. Weinblatt, M.E.; Mease, P.; Mysler, E.; Takeuchi, T.; Drescher, E.; Berman, A.; Xing, J.; Zilberstein, M.; Banerjee, S.; Emery, P. The Efficacy and Safety of Subcutaneous Clazakizumab in Patients with Moderate-to-Severe Rheumatoid Arthritis and an Inadequate Response to Methotrexate. Arthritis Rheumatol. 2015, 67, 2591-2600. [CrossRef] [PubMed]

113. Mease, P.J.; Gottlieb, A.B.; Berman, A.; Drescher, E.; Xing, J.; Wong, R.; Banerjee, S. The Efficacy and Safety of Clazakizumab, an Anti-Interleukin-6 Monoclonal Antibody, in a Phase Ilb Study of Adults With Active Psoriatic Arthritis. Arthritis Rheumatol. 2016, 68, 2163-2173. [CrossRef] [PubMed]

114. Cook, D.N.; Kang, H.S.; Jetten, A.M. Retinoic acid orphan receptors (RORs): Regulatory functions in immunity, development, circadian rhythm and metabolism. Nucl. Recept. Res. 2015, 2, 101185. [CrossRef] [PubMed]

115. Fujita-Sato, S.; Ito, S.; Isobe, T.; Ohyama, T.; Wakabayashi, K.; Morishita, K.; Ando, O.; Isono, F. Structural basis of digoxin that antagonizes ROR $\gamma \mathrm{t}$ receptor activity and suppresses Th17 cell differentiation and interleukin (IL)-17 production. J. Biol. Chem. 2011, 286, 31409-31417. [CrossRef] [PubMed]

116. Huh, J.R.; Leung, M.W.L.; Huang, P.; Ryan, D.A.; Michael, R.; Malapaka, R.R.V.; Chow, J.; Manel, N.; Ciofani, M.; Kim, S.V.; et al. Digoxin and its derivatives suppress Th17 cell differentiation by antagonizing ROR $\gamma$ t activity. Nature 2011, 472, 486-490. [CrossRef] [PubMed]

117. Lee, J.; Baek, S.; Lee, J.; Lee, J.; Lee, D.; Park, M.; Cho, M.; Park, S.; Kwok, S. Digoxin ameliorates autoimmune arthritis via suppression of Th17 differentiation. Int. Immunopharmacol. 2015, 26, 103-111. [CrossRef] [PubMed]

118. Baek, S.-Y.; Lee, J.J.; Lee, D.-G.; Park, M.-K.; Lee, J.J.; Kwok, S.-K.; Cho, M.; Park, S.-H. Ursolic acid ameliorates autoimmune arthritis via suppression of Th17 and B cell differentiation. Acta Pharmacol. Sin. 2014, 35, 1-11. [CrossRef] [PubMed]

119. Xiao, S.; Yosef, N.; Yang, J.; Wang, Y.; Zhou, L.; Zhu, C.; Wu, C.; Baloglu, E.; Schmidt, D.; Ramesh, R.; et al. Small-molecule ROR $\gamma \mathrm{t}$ antagonists inhibit $\mathrm{T}$ helper 17 cell transcriptional network by divergent mechanisms. Immunity 2014, 40, 477-489. [CrossRef] [PubMed]

120. Skepner, J.; Trocha, M.; Ramesh, R.; Qu, X.A.; Schmidt, D.; Baloglu, E.; Lobera, M.; Davis, S.; Nolan, M.A.; Thaddeus, J.; et al. In vivo regulation of gene expression and T helper type 17 differentiation by ROR $\gamma \mathrm{t}$ inverse agonists. Immunology 2014, 145, 347-356. [CrossRef] [PubMed] 
121. Skepner, J.; Ramesh, R.; Trocha, M.; Schmidt, D.; Baloglu, E.; Lobera, M.; Carlson, T.; Hill, J.; Orband-Miller, L.A.; Barnes, A.; et al. Pharmacologic Inhibition of ROR $\gamma t$ Regulates Th17 Signature Gene Expression and Suppresses Cutaneous Inflammation In Vivo. J. Immunol. 2014, 192, 2564-2575. [CrossRef] [PubMed]

122. Takaishi, M.; Ishizaki, M.; Suzuki, K.; Isobe, T.; Shimozato, T.; Sano, S. Oral administration of a novel ROR $\gamma \mathrm{t}$ antagonist attenuates psoriasis-like skin lesion of two independent mouse models through neutralization of IL-17. J. Dermatol. Sci. 2016. [CrossRef] [PubMed]

123. Smith, S.H.; Peredo, C.E.; Takeda, Y.; Bui, T.; Neil, J.; Rickard, D.; Millerman, E.; Therrien, J.P.; Nicodeme, E.; Brusq, J.M.; et al. Development of a topical treatment for psoriasis targeting ROR $\gamma$ : From bench to skin. PLoS ONE 2016, 11, e0147979. [CrossRef] [PubMed]

124. Gege, C. Retinoid-related orphan receptor gamma t (ROR $\gamma \mathrm{t})$ inhibitors from Vitae Pharmaceuticals (WO2015116904) and structure proposal for their Phase I candidate VTP-43742. Expert Opin. Ther. Pat. 2016, 26, 737-744. [CrossRef] [PubMed]

125. Wu, Q.; Nie, J.; Gao, Y.; Xu, P.; Sun, Q.; Yang, J.; Han, L. Reciprocal regulation of ROR $\gamma$ t acetylation and function by p300 and HDAC1. Sci. Rep. 2015, 5, 16355. [CrossRef] [PubMed]

126. Lim, H.W.; Kang, S.G.; Ryu, J.K.; Schilling, B.; Fei, M.; Lee, I.S.; Kehasse, A.; Shirakawa, K.; Yokoyama, M.; Schnolzer, M.; et al. SIRT1 deacetylates ROR $\gamma$ t and enhances Th17 cell generation. J. Exp. Med. 2015, 212, 607-617. [CrossRef] [PubMed]

127. Wang, X.; Yang, J.; Han, L.; Zhao, K.; Wu, Q.; Bao, L.; Li, Z.; Lv, L.; Li, B. TRAF5-mediated Lys-63-linked polyubiquitination plays an essential role in positive regulation of ROR $\gamma \mathrm{t}$ in promoting IL-17A expression. J. Biol. Chem. 2015, 290, 29086-29094. [CrossRef] [PubMed]

128. Rutz, S.; Kayagaki, N.; Phung, Q.T.; Eidenschenk, C.; Noubade, R.; Wang, X.; Lesch, J.; Lu, R.; Newton, K.; Huang, O.W.; et al. Deubiquitinase DUBA is a post-translational brake on interleukin-17 production in T cells. Nature 2015, 518, 417-421. [CrossRef] [PubMed]

129. Kathania, M.; Khare, P.; Zeng, M.; Cantarel, B.; Zhang, H.; Ueno, H.; Venuprasad, K. Itch inhibits IL-17-mediated colon inflammation and tumorigenesis by ROR- $\gamma$ t ubiquitination. Nat. Immunol. 2016, 17, 997-1004. [CrossRef] [PubMed]

130. He, Z.; Wang, F.; Ma, J.; Sen, S.; Zhang, J.; Gwack, Y.; Zhou, Y.; Sun, Z. Ubiquitination of ROR $\gamma t$ at Lysine 446 Limits Th17 Differentiation by Controlling Coactivator Recruitment. J. Immunol. 2016, 197, 1148-1158. [CrossRef] [PubMed]

131. Han, L.; Yang, J.; Wang, X.; Wu, Q.; Yin, S.; Li, Z.; Zhang, J.; Xing, Y.; Chen, Z.; Tsun, A.; et al. The E3 deubiquitinase USP17 is a positive regulator of retinoic acid-related orphan nuclear receptor $\gamma \mathrm{t}(\mathrm{ROR} \gamma \mathrm{t})$ in Th17 cells. J. Biol. Chem. 2014, 289, 25546-25555. [CrossRef] [PubMed]

132. Babon, J.J.; Varghese, L.N.; Nicola, N.A. Inhibition of IL-6 family cytokines by SOCS3. Semin. Immunol. 2014, 26, 13-19. [CrossRef] [PubMed]

133. Wolf, J.; Rose-John, S.; Garbers, C. Interleukin-6 and its receptors: A highly regulated and dynamic system. Cytokine 2014, 70, 11-20. [CrossRef] [PubMed]

134. Hodge, J.A.; Kawabata, T.T.; Krishnaswami, S.; Clark, J.D.; Telliez, J.; Dowty, M.E.; Menon, S.; Lamba, M.; Zwillich, S.; Hodge, J.A.; et al. The mechanism of action of tofacitinib-An oral Janus kinase inhibitor for the treatment of rheumatoid arthritis. Clin. Exp. Rheumatol. 2016, 34, 318-328. [PubMed]

135. Meyer, D.M.; Jesson, M.I.; Li, X.; Elrick, M.M.; Funckes-shippy, C.L.; Warner, J.D.; Gross, C.J.; Dowty, M.E.; Ramaiah, S.K.; Hirsch, J.L.; et al. Anti-inflammatory activity and neutrophil reductions mediated by the JAK1/JAK3 inhibitor, CP-690,550, in rat adjuvant-induced arthritis. J. Inflamm. 2010, 7, 41. [CrossRef] [PubMed]

136. Boyle, D.L.; Soma, K.; Hodge, J.; Kavanaugh, A.; Mandel, D.; Mease, P.; Shurmur, R.; Singhal, A.K.; Wei, N.; Rosengren, S.; et al. The JAK inhibitor tofacitinib suppresses synovial JAK1-STAT signalling in rheumatoid arthritis. Ann. Rheum. Dis. 2015, 74, 1311-1316. [CrossRef] [PubMed]

137. Ghoreschi, K.; Jesson, M.I.; Li, X.; Jamie, L.; Ghosh, S.; Alsup, J.W.; Warner, J.D.; Tanaka, M.; Steward-tharp, S.M.; Gadina, M.; et al. Modulation of Innate and Adaptive Immune Responses by Tofacitinib (CP-690,550). J. Immunol. 2011, 186, 4234-4243. [CrossRef] [PubMed]

138. Bachelez, H.; van de Kerkhof, P.C.M.; Strohal, R.; Kubanov, A.; Valenzuela, F.; Lee, J.; Yakusevich, V. Tofacitinib versus etanercept or placebo in moderate-to-severe chronic plaque psoriasis: A phase 3 randomised non-inferiority trial. Lancet 2015, 386, 552-561. [CrossRef] 
139. Valenzuela, F.; Paul, C.; Mallbris, L.; Tan, H.; Papacharalambous, J.; Valdez, H.; Mamolo, C. Tofacitinib versus etanercept or placebo in patients with moderate to severe chronic plaque psoriasis: Patient-reported outcomes from a Phase 3 study. JEADV 2016, 30, 1753-1759. [CrossRef] [PubMed]

140. Papp, K.A.; Krueger, J.G.; Feldman, S.R. Tofacitinib, an oral Janus kinase inhibitor, for the treatment of chronic plaque psoriasis: Long-term efficacy and safety results from 2 randomized phase-III studies and 1 open-label long-term extension study. J. Am. Acad. Dermatol. 2016, 74, 841-850. [CrossRef] [PubMed]

141. Gao, W.; McGarry, T.; Orr, C.; McCormick, J.; Veale, D.J.; Fearon, U. Tofacitinib regulates synovial inflammation in psoriatic arthritis, inhibiting STAT activation and induction of negative feedback inhibitors. Ann. Rheum. Dis. 2016, 75, 311-315. [CrossRef] [PubMed]

142. Izzo, R.; Bevivino, G.; Monteleone, G. Tofacitinib for the treatment of ulcerative colitis. Expert Opin. Investig. Drugs 2016, 8, 991-997. [CrossRef] [PubMed]

143. Danese, S.; Grisham, M.; Hodge, J.; Telliez, J. JAK inhibition using tofacitinib for inflammatory bowel disease treatment: A hub for multiple inflammatory cytokines. Am. J. Physiol. Gastrointest. Liver Physiol. 2016, 310, G155-G162. [CrossRef] [PubMed]

144. Park, J.S.; Kwok, S.K.; Lim, M.A.; Kim, E.K.; Ryu, J.G.; Kim, S.M.; Oh, H.J.; Ju, J.H.; Park, S.H.; Kim, H.Y.; et al. La STA-21, a promising STAT-3 inhibitor that reciprocally regulates Th17 and Treg cells, inhibits osteoclastogenesis in mice and humans and alleviates autoimmune inflammation in an experimental model of rheumatoid arthritis. Arthritis Rheumatol. 2014, 66, 918-929. [CrossRef] [PubMed]

145. Wu, H.; Yan, S.; Chen, J.; Luo, X.; Li, P. JAK1-STAT3 blockade by JAK inhibitor SHR0302 attenuates inflammatory responses of adjuvant-induced arthritis rats and decreases Th17 and total B cells. Jt. Bone Spine 2016, 83, 525-532. [CrossRef] [PubMed]

146. Yang, E.J.; Lee, J.; Lee, S.Y.; Kim, E.K.; Moon, Y.M.; Jung, Y.O.; Park, S.H.; Cho, M.L. EGCG attenuates autoimmune arthritis by inhibition of STAT3 and HIF-1 $\alpha$ pathway with Th17/Treg control. PLoS ONE 2014, 9, e86062.

147. Astry, B.; Venkatesha, S.H.; Laurence, A.; Christensen-Quick, A.; Garzino-demo, A.; Frieman, M.B.; O'Shea, J.J.; Moudgil, K.D. Celastrol, a Chinese herbal compound, controls autoimmune inflammation by altering the balance of pathogenic and regulatory T cells in the target organ. Clin. Immunol. 2015, 157, 228-238. [CrossRef] [PubMed]

148. Jhun, J.Y.; Moon, S.J.; Yoon, B.Y.; Byun, J.K.; Kim, E.K.; Yang, E.J.; Ju, J.H.; Hong, Y.S.; Min, J.K.; Park, S.H.; et al. La Grape seed proanthocyanidin extract-mediated regulation of STAT3 proteins contributes to Treg differentiation and attenuates inflammation in a murine model of obesity-associated arthritis. PLoS ONE 2013, 8, e78843. [CrossRef] [PubMed]

149. Moon, S.J.; Park, J.S.; Woo, Y.J.; Lim, M.A.; Kim, S.M.; Lee, S.Y.; Kim, E.K.; Lee, H.J.; Lee, W.S.; Park, S.H.; et al. Rebamipide suppresses collagen-induced arthritis through reciprocal regulation of Th17/Treg cell differentiation and heme oxygenase 1 induction. Arthritis Rheumatol. 2014, 66, 874-885. [CrossRef] [PubMed]

150. Park, M.K.; Park, J.S.; Park, E.M.; Lim, M.A.; Kim, S.M.; Lee, D.G.; Baek, S.Y.; Yang, E.J.; Woo, J.W.; Lee, J.; et al. Halofuginone ameliorates autoimmune arthritis in mice by regulating the balance between Th17 and treg cells and inhibiting osteoclastogenesis. Arthritis Rheumatol. 2014, 66, 1195-1207. [CrossRef] [PubMed]

151. Sun, Y.; Tian, T.; Gao, J.; Liu, X.; Hou, H.; Cao, R.; Li, B.; Quan, M.; Guo, L. Metformin ameliorates the development of experimental autoimmune encephalomyelitis by regulating $\mathrm{T}$ helper 17 and regulatory T cells in mice. J. Neuroimmunol. 2016, 292, 58-67. [CrossRef] [PubMed]

152. Fontenot, J.D.; Gavin, M.A.; Rudensky, A.Y. Foxp3 programs the development and function of CD4+CD25+ regulatory T cells. Nat. Immunol. 2003, 4, 330-336. [CrossRef] [PubMed]

153. Hori, S.; Nomura, T. Saka Control of Regulatory T Cell Development by the Transcription Factor Foxp3. Science 2003, 299, 1057-1061. [CrossRef] [PubMed]

154. Ohata, J.; Miura, T.; Johnson, T.A.; Hori, S.; Ziegler, S.F.; Kohsaka, H. Enhanced efficacy of regulatory T cell transfer against increasing resistance, by elevated Foxp3 expression induced in arthritic murine hosts. Arthritis Rheum. 2007, 56, 2947-2956. [CrossRef] [PubMed]

155. Zhou, L.; Lopes, J.E.; Chong, M.M.W.; Ivanov, I.I.; Min, R.; Victora, G.D.; Shen, Y.; Du, J.; Rubtsov, Y.P.; Rudensky, A.Y.; et al. TGF- $\beta$-induced Foxp3 inhibits Th17 cell differentiation by antagonizing ROR $\gamma \mathrm{t}$ function. Nature 2008, 453, 236-241. [CrossRef] [PubMed] 
156. Quaglino, P.; Bergallo, M.; Ponti, R.; Barberio, E.; Cicchelli, S.; Buffa, E.; Comessatti, A.; Costa, C.; Terlizzi, M.E.; Astegiano, S.; et al. Th1, Th2, Th17 and regulatory T cell pattern in psoriatic patients: Modulation of cytokines and gene targets induced by etanercept treatment and correlation with clinical response. Dermatology 2011, 223, 57-67. [CrossRef] [PubMed]

157. Lina, C.; Conghua, W.; Nan, L.; Ping, Z. Combined treatment of etanercept and MTX reverses Th1/Th2, Th17/Treg imbalance in patients with rheumatoid arthritis. J. Clin. Immunol. 2011, 31, 596-605. [CrossRef] [PubMed]

158. Nguyen, Q.D.; Merrill, P.T.; Jaffe, G.J.; Dick, A.D.; Kurup, S.K.; Sheppard, J.; Schlaen, A.; Pavesio, C.; Cimino, L.; van Calster, J.; et al. Adalimumab for prevention of uveitic flare in patients with inactive non-infectious uveitis controlled by corticosteroids (VISUAL II): A multicentre, double-masked, randomised, placebo-controlled phase 3 trial. Lancet 2016, 6736, 1-10. [CrossRef]

159. Orban, T.; Bundy, B.; Becker, D.J.; DiMeglio, L.A.; Gitelman, S.E.; Goland, R.; Gottlieb, P.A.; Greenbaum, C.J.; Marks, J.B.; Monzavi, R.; et al. Co-stimulation modulation with abatacept in patients with recent-onset type 1 diabetes: A randomised, double-blind, placebo-controlled trial. Lancet 2011, 378, 412-419. [CrossRef]

160. Emery, P. Optimizing outcomes in patients with rheumatoid arthritis and an inadequate response to anti-TNF treatment. Rheumatology 2012, 51, 22-30. [CrossRef] [PubMed]

161. Sansom, D.M.; Walker, L.S.K. The role of CD28 and cytotoxic T-lymphocyte antigen-4 (CTLA-4) in regulatory T-cell biology. Immunol. Rev. 2006, 212, 131-148. [CrossRef] [PubMed]

162. Bonelli, M.; Göschl, L.; Blüml, S.; Karonitsch, T.; Hirahara, K.; Ferner, E.; Steiner, C.W.; Steiner, G.; Smolen, J.S.; Scheinecker, C. Abatacept (CTLA-4Ig) treatment reduces $\mathrm{T}$ cell apoptosis and regulatory $\mathrm{T}$ cell suppression in patients with rheumatoid arthritis. Rheumatology 2016, 55, 710-720. [CrossRef] [PubMed]

163. Sfikakis, P.P.; Souliotis, V.L.; Fragiadaki, K.G.; Moutsopoulos, H.M.; Boletis, J.N.; Theofilopoulos, A.N. Increased expression of the FoxP3 functional marker of regulatory $\mathrm{T}$ cells following $\mathrm{B}$ cell depletion with rituximab in patients with lupus nephritis. Clin. Immunol. 2007, 123, 66-73. [CrossRef] [PubMed]

164. Floess, S.; Freyer, J.; Siewert, C.; Baron, U.; Olek, S.; Polansky, J.; Schlawe, K.; Chang, H.D.; Bopp, T.; Schmitt, E.; et al. Epigenetic control of the foxp3 locus in regulatory T cells. PLoS Biol. 2007, 5, 169-178. [CrossRef] [PubMed]

165. Lal, G.; Zhang, N.; van der Touw, W.; Ding, Y.; Ju, W.; Bottinger, E.P.; Reid, S.P.; Levy, D.E.; Bromberg, J.S. Epigenetic regulation of Foxp3 expression in regulatory T cells by DNA methylation. J. Immunol. 2009, 182, 259-273. [CrossRef] [PubMed]

166. Cribbs, A.P.; Kennedy, A.; Penn, H.; Amjadi, P.; Green, P.; Read, J.E.; Brennan, F.; Gregory, B.; Williams, R.O. Methotrexate restores regulatory $\mathrm{T}$ cell function through demethylation of the FoxP3 upstream enhancer in patients with rheumatoid arthritis. Arthritis Rheumatol. 2015, 67, 1182-1192. [CrossRef] [PubMed]

167. Shin, H.-J.; Baker, J.; Leveson-Gower, D.B.; Smith, A.T.; Sega, E.I.; Negrin, R.S. Rapamycin and IL-2 reduce lethal acute graft-versus-host disease associated with increased expansion of donor type CD4+CD25+Foxp3+ regulatory T cells. Blood 2011, 118, 2342-2350. [CrossRef] [PubMed]

168. Golovina, T.N.; Mikheeva, T.; Brusko, T.M.; Blazar, B.R.; Bluestone, J.A.; Riley, J.L. Retinoic acid and rapamycin differentially affect and synergistically promote the ex vivo expansion of natural human $\mathrm{T}$ regulatory cells. PLoS ONE 2011, 6, e15868. [CrossRef] [PubMed]

169. Wang, L.; Tao, R.; Hancock, W.W. Using histone deacetylase inhibitors to enhance Foxp3(+) regulatory T-cell function and induce allograft tolerance. Immunol. Cell Biol. 2009, 87, 195-202. [CrossRef] [PubMed]

170. Liu, Y.; Wang, L.; Predina, J.; Han, R.; Beier, U.H.; Wang, L.C.; Kapoor, V.; Bhatti, T.R.; Akimova, T.; Singhal, S.; et al. Inhibition of p300 impairs Foxp3+ T regulatory cell function and promotes antitumor immunity. Nat. Med. 2013, 19, 1173-1177. [CrossRef] [PubMed]

171. Tao, R.; de Zoeten, E.F.; Ozkaynak, E.; Chen, C.; Wang, L.; Porrett, P.M.; Li, B.; Turka, L.A.; Olson, E.N.; Greene, M.I.; et al. Deacetylase inhibition promotes the generation and function of regulatory $\mathrm{T}$ cells. Nat. Med. 2007, 13, 1299-1307. [CrossRef] [PubMed]

172. De Zoeten, E.F.; Wang, L.; Butler, K.; Beier, U.H.; Akimova, T.; Sai, H.; Bradner, J.E.; Mazitschek, R.; Kozikowski, A.P.; Matthias, P.; et al. Histone deacetylase 6 and heat shock protein 90 control the functions of Foxp3+ T-regulatory cells. Mol. Cell. Biol. 2011, 31, 2066-2078. [CrossRef] [PubMed]

173. Beier, U.H.; Akimova, T.; Liu, Y.; Wang, L.; Hancock, W.W. Histone/protein deacetylases control Foxp3 expression and the heat shock response of T-regulatory cells. Curr. Opin. Immunol. 2011, 23, 670-678. [CrossRef] [PubMed] 
174. Xiao, H.; Jiao, J.; Wang, L.; O’Brien, S.; Newick, K.; Wang, L.C.S.; Falkensammer, E.; Liu, Y.; Han, R.; Kapoor, V.; et al. HDAC5 controls the functions of Foxp3+ T-regulatory and CD8+ T cells. Int. J. Cancer 2016, 138, 2477-2486. [CrossRef] [PubMed]

175. Lainé, A.; Martin, B.; Luka, M.; Mir, L.; Auffray, C.; Lucas, B.; Bismuth, G. Foxo1 Is a T Cell-Intrinsic Inhibitor of the ROR $\gamma \mathrm{t}$-Th17 Program. J. Immunol. 2015, 195, 1791-1803. [CrossRef] [PubMed]

176. Ichiyama, K.; Gonzalez-Martin, A.; Kim, B.; Jin, H.; Jin, W.; Xu, W.; Sabouri-Ghomi, M.; Xu, S.; Zheng, P.; Xiao, C.; et al. The MicroRNA-183-96-182 Cluster Promotes T Helper 17 Cell Pathogenicity by Negatively Regulating Transcription Factor Foxo1 Expression. Immunity 2016, 44, 1284-1298. [CrossRef] [PubMed]

177. Wan, C.; Ping, C.; Shang, X.; Tian, J.; Zhao, S.; Li, L.; Fang, S.; Sun, W.; Zhao, Y.; Li, Z.; et al. MicroRNA 182 inhibits CD4+CD25+Foxp3+ Treg differentiation in experimental autoimmune encephalomyelitis. Clin. Immunol. 2016, 173, 109-116. [CrossRef] [PubMed]

178. Wang, X.; Yu, Y.; Gu, L. Dehydroabietic acid reverses TNF- $\alpha$-induced the activation of FOXO1 and suppression of TGF- $\beta 1 /$ Smad signaling in human adult dermal fibroblasts. Int. J. Clin. Exp. Pathol. 2014, 7, 8616-8626. [PubMed]

179. Liu, Y.; Luo, W.; Chen, S. Comparison of gene expression profiles reveals aberrant expression of FOXO1, Aurora A/B and EZH2 in lesional psoriatic skins. Mol. Biol. Rep. 2011, 38, 4219-4224. [CrossRef] [PubMed]

180. Liao, L.; Su, X.; Yang, X.; Hu, C.; Li, B.; Lv, Y.; Shuai, Y.; Jing, H.; Deng, Z.; Jin, Y. TNF- $\alpha$ Inhibits FoxO1 by Upregulating miR-705 to Aggravate Oxidative Damage in Bone Marrow- Derived Mesenchymal Stem Cells during Osteoporosis. Stem Cells 2016, 34, 1054-1067. [CrossRef] [PubMed]

181. Ehrenstein, M.R.; Evans, J.G.; Singh, A.; Moore, S.; Warnes, G.; Isenberg, D.A.; Mauri, C.; Wca, L. Compromised Function of Regulatory T Cells in Rheumatoid Arthritis and Reversal by Anti-TNF $\alpha$ Therapy. J. Exp. Med. 2004, 200, 277-285. [CrossRef] [PubMed]

182. Shen, H.; Xia, L.; Lu, J.; Xiao, W. Infliximab Reduces the Frequency of Interleukin 17-Producing Cells and the Amounts of Interleukin 17 in Patients With Rheumatoid Arthritis. J. Investig. Med. 2010, 58, 905-908. [CrossRef] [PubMed]

183. Aravena, O.; Pesce, B.; Soto, L.; Orrego, N.; Sabugo, F.; Wurmann, P.; Molina, M.C.; Alfaro, J.; Cuchacovich, M.; Aguillón, J.C.; et al. Anti-TNF therapy in patients with rheumatoid arthritis decreases Th1 and Th17 cell populations and expands IFN- $\gamma$-producing NK cell and regulatory T cell subsets. Immunobiology 2011, 216, 1256-1263. [CrossRef] [PubMed]

184. Hernandez, A.L.; Kitz, A.; Wu, C.; Lowther, D.E.; Rodriguez, D.M.; Vudattu, N.; Deng, S.; Herold, K.C.; Kuchroo, V.K.; Kleinewietfeld, M.; et al. Sodium chloride inhibits the suppressive function of FOXP3+ regulatory T cells. J. Clin. Investig. 2015, 125, 4212-4222. [CrossRef] [PubMed]

185. Luo, C.T.; Liao, W.; Dadi, S.; Toure, A.; Li, M.O. Graded Foxo1 activity in Treg cells differentiates tumour immunity from spontaneous autoimmunity. Nature 2016, 529, 532-536. [CrossRef] [PubMed]

186. Ciofani, M.; Madar, A.; Galan, C.; Sellars, M.; Mace, K.; Pauli, F.; Agarwal, A.; Huang, W.; Parkhurst, C.N.; Newberry, K.M.; et al. A validated regulatory network for Th17 cell specification. Cell 2012, 151, 289-303. [CrossRef] [PubMed]

187. Biswas, P.S.; Gupta, S.; Chang, E.; Song, L.; Stirzaker, R.A.; Liao, J.K.; Bhagat, G.; Pernis, A.B. Phosphorylation of IRF4 by ROCK2 regulates IL-17 and IL-21 production and the development of autoimmunity in mice. J. Clin. Investig. 2010, 120, 3280-3295. [CrossRef] [PubMed]

188. He, Y.; Xu, H.; Liang, L.; Zhan, Z.; Yang, X.; Yu, X.; Ye, Y.; Sun, L. Antiinflammatory effect of Rho kinase blockade via inhibition of NF-kappaB activation in rheumatoid arthritis. Arthritis Rheum. 2008, 58, 3366-3376. [CrossRef] [PubMed]

189. Isgro, J.; Gupta, S.; Jacek, E.; Pavri, T.; Duculan, R.; Kim, M.; Kirou, K.A.; Salmon, J.E.; Pernis, A.B. Enhanced Rho-Associated Protein Kinase Activation in Patients With Systemic Lupus Erythematosus. Arthritis Rheum. 2013, 65, 1592-1602. [CrossRef] [PubMed]

190. Zanin-Zhorov, A.; Weiss, J.M.; Nyuydzefe, M.S.; Chen, W.; Scher, J.U.; Mo, R. Selective oral ROCK2 inhibitor down-regulates IL-21 and IL-17 secretion in human T cells via STAT3-dependent mechanism. Proc. Natl. Acad. Sci. USA 2014, 111, 16814-16819. [CrossRef] [PubMed]

191. Flynn, R.; Paz, K.; Du, J.; Reichenbach, D.K.; Taylor, P.A.; Panoskaltsis-mortari, A.; Vulic, A.; Luznik, L.; Macdonald, K.K.P.; Hill, G.R.; et al. Targeted Rho-associated kinase 2 inhibition suppresses murine and human chronic GVHD through a Stat3-dependent mechanism. Blood 2016, 127, 2144-2155. [CrossRef] [PubMed] 
192. Zhao, Y.; Zhang, X.; Ding, Z.; Yang, X.; Zhang, H. The Therapeutic Potential of Rho Kinase Inhibitor Fasudil Derivative FaD-1 in Experimental Autoimmune Encephalomyelitis. J. Mol. Neurosci. 2015, 55, 725-732. [CrossRef] [PubMed]

193. Li, Y.; Yu, J.; Xin, Y.; Feng, L.; Chai, Z.; Liu, J.; Zhang, H. Protective effect of a novel Rho kinase inhibitor WAR-5 in experimental autoimmune encephalomyelitis by modulating inflammatory response and neurotrophic factors. Exp. Mol. Pathol. 2015, 99, 220-228. [CrossRef] [PubMed]

194. Joetham, A.; Ohnishi, H.; Okamoto, M.; Takeda, K.; Schedel, M.; Domenico, J.; Dakhama, A.; Gelfand, E.W. Loss of T Regulatory Cell Suppression following Signaling through Glucocorticoid-induced Tumor Necrosis Receptor (GITR) Is Dependent on c-Jun N-terminal Kinase Activation. J. Biol. Chem. 2012, 287, 17100-17108. [CrossRef] [PubMed]

195. Wang, S.; Shi, Y.; Yang, M.; Ma, J.; Tian, J.; Chen, J.; Mao, C.; Jiao, Z.; Ko, K.; Lu, L. Glucocorticoid-Induced Tumor Necrosis Factor Receptor Family-Related Protein Exacerbates Collagen-Induced Arthritis by Enhancing the Expansion of Th17 Cells. Am. J. Pathol. 2012, 180, 1059-1067. [CrossRef] [PubMed]

196. Tang, X.; Tian, J.; Ma, J.; Wang, J.; Qi, C.; Rui, K.; Wang, Y.; Xu, H.; Lu, L.; Wang, S. GITRL modulates the activities of p38 MAPK and STAT3 to promote Th17 cell differentiation in autoimmune arthritis. Oncotarget 2015, 7. [CrossRef]

197. Li, L.; Wen, W.; Jia, R.; Li, Y.; Liu, X.; Sun, X. GITRL is associated with increased autoantibody production in patients with rheumatoid arthritis. Clin. Rheumatol. 2016, 35, 2195-2202. [CrossRef] [PubMed]

198. Cohen, S.B.; Cheng, T.; Chindalore, V.; Damjanov, N.; Burgos-vargas, R.; Delora, P.; Zimany, K.; Travers, H.; Caulfield, J.P. Evaluation of the efficacy and safety of pamapimod, a p38 MAP kinase inhibitor, in a double-blind, methotrexate-controlled study of patients with active rheumatoid arthritis. Arthritis Rheum. 2009, 60, 335-344. [CrossRef] [PubMed]

(C) 2017 by the authors; licensee MDPI, Basel, Switzerland. This article is an open access article distributed under the terms and conditions of the Creative Commons Attribution (CC-BY) license (http://creativecommons.org/licenses/by/4.0/). 